\title{
MATTA-rakenteen kognitiivista semantiikkaa
}

\author{
Markus Hamunen
}

Tämä artikkeli käsittelee suomen 3. infinitiivin abessiivin eli MA-infinitiivin abessiivin muodostaman adverbiaalisen infinitiivirakenteen (jatkossa MATTA-rakenne ${ }^{1}$, esim. mukisematta, tekemättä) semantiikkaa murreaineiston valossa. Havainnollistan tutkimaani ilmiötä seuraavilla esimerkeillä. Esimerkissä 1a syhymät ('syyhyämättä) ja kraappimat ('raapimatta') ovat subjektitarkoitteen tulkinnaltaan samatekijäisiä kuin finiittiverbin geneerinen nollapersoona. Vastaavasti esimerkissä 1b MATTA-rakenne kussumata ('kutsumatta') on eritekijäinen suhteessa finiittiverbiin. Infinitiivin oma subjekti on ilmipanematon nollapersoona. Se on tulkinnaltaan sama kuin lausuman aiemman passiivin kussuttii ('kutsuttiin') taka-alaistama tekijä. Vastaavasti hallitsevan rakenteen ne män sitte häihi subjekti tulkitaan infinitiivin objektiksi.

(1) a. ko syhymät sauna mene ni ei kraappimat pois pääs ko, semmot vanha aikka sanotti ai (DMA, Mietoinen)

b. ei muuta ko morsiamme puole läksiäisii kussuttii morsiamme sukulaiset ja siit jos niitä läks ketä saattammaa ni ne män sitte häihi ilma kussumata (LA, Nuijamaa)

Määrittelen MATTA-rakenteen sellaiseksi $m A t t A$-infinitiiviksi, joka toimii pääsääntöisesti finiittiverbillisten lausumien vapaana adverbiaalina (esim. 1a-b). Voi kysyä: Mikä on MATTA-rakenteen merkitys finiittirakenteen adjunktina? Mitä kielteinen infinitiivimuoto kieltää? Millaisena konstruktiokieliopin mukaisena konstruktiona rakennetta voi pitää?

1. Iso suomen kielioppi (2004 \$515) käyttää morfofonologista merkintää mAttA-rakenne, joka korostaa infinitiivimuodon yleiskielisen muodon morfofonemaattista vaihtelua (ostamatta, tekemättä). Käytän tässä tutkimuksessa konstruktiokieliopissa sovellettua tapaa nimetä konstruktio (tai sen edustavin osa) kapiteelikirjaimin, mikä sekä on riittävän kuvaava keino kielellisen rakenteen tunnistamiseksi että pitää samalla sisällään ajatuksen konstruktioon kaikkinensa liittyvistä ilmiöistä (MATTA-rakenteen osalta mm. sen lausemaisuus, sen "omat" lauseenjäsenet, muodollinen variaatio ja semantiikkaan liittyvät tekijät). Nimitys myös rajaa tarkastelun vain $m A t t A$-infinitiivin adverbiaalikäyttöihin. (Ks. myös Hamunen 2017: alav. 2.) 
Konkreettisen lähtökohdan edellä esitetyille kysymyksille antaa seuraava Isossa suomen kieliopissa (ISK $2004 \$ 515$ ) esitetty luonnehdinta:

Kielteinen $m A t t A$-rakenne ilmaisee, että hallitsevan lauseen [finiittilauseen] kuvaama tilanne toteutuu tai voi toteutua ilman sen tarkoittamaa toimintaa (» \$1627). Rakenne on vähemmän spesifinen kuin en- [TEN-rakenne, esim. ajatellen, juosten] ja mAllArakenteet [MALLA-rakenne, esim. ajattelemalla, juoksemalla] ja toimii molempien kielteisenä vastineena[.] [lisäykset ja korostus $\mathrm{MH}$ ]

Sinänsä perustelematta esitetty ajatus MATTA-rakenteen ja tapaa väljästi kuvaavien TEN- ja MALLA-rakenteiden (näistä ks. Hamunen 2017) vastineisuudesta on intuitiivisesti jotenkin vetoava: kaikki ovat infinitiivirakenteita, ne ovat samassa syntaktisessa asemassa suhteessa hallitsevaan rakenteeseen (adjunkteja), ja TEN- ja MALLA-rakenteet ovat toistensa lähikonstruktioita (Hamunen ma.). Esimerkki 2 kuvaa minimipareja, mutta voidaan kysyä, muodostavatko infinitiivirakenteet funktionaalisesti yhtenäisen lähikonstruktioiden ryhmän Ison suomen kieliopin (mp.) esittämällä tavalla.

(2) Hän tuli paikalle juosten $\sim$ juoksemalla $\sim$ juoksematta.

Edellä esitetyn perusteella rakenteen kielteisyyttä koskevan kysymyksen voi siis jakaa vielä kolmeen alakysymykseen: 1) Onko MATTA-rakenne ymmärrettävä juuri TENja MALLA-rakenteiden kielteisenä vastineena ja tämä infinitiivirakennejoukko lähikonstruktioiden ryhmänä? 2) Ulottuuko rakenteen kielteisyys muualle; toisin sanoen onko MATTA-rakenteella mahdollisesti semanttinen kytkentä joihinkin muihin (myönteisiin) rakenteisiin? 3) Kuinka alakysymysten 1 ja 2 muodostamaa kokonaisuutta voisi kuvata yhtenäisessä teoreettisessa kehyksessä?

Artikkelin kulku on seuraava: Luvussa 1 esittelen käyttämäni murrekorpukset ja menettelytavan, jolla seuloin tutkimuskohteen keräämästäni aineistosta. Luvussa 2 avaan MATTA-rakenteen tulkinnalle keskeistä abessiivisuutta ja negaatiota käsitteistyksenä. Luvussa 3 tarkastelen MATTA-rakennetta TEN- ja MALLA-rakenteiden lähikonstruktiona eli kielteisenä vastineena (alakysymys 1) ja luvussa 4 esitän MATTA-rakenteelle yhtenäisen kehyssemanttisen kuvauksen konstruktiokieliopin puitteissa (alakysymykset 2 ja 3). Luvussa 5 kertaan löydökset ja tiivistän MATTA-rakenteen luonteen tutkimuskysymysten valossa. $^{2}$

\section{Aineisto ja tutkimuskohteen seulominen}

Aineistona käytän pääasiassa korpuksista poimittua murreaineistoa mutta toisinaan myös kielitajulla tuotettuja esimerkkejä. Murre-esimerkit tarjoavat autenttista evidenssiä

2. Lausun kiitokseni Virittäjän kahdelle nimettömälle arvioijalle tarkoista huomioista sekä erikseen Ilona Herlinille, Marko Pantermöllerille ja Jussi Ylikoskelle käsikirjoituksen eri versioiden kommentoinnista ja muusta avusta. Kaikki virheet ja puutteet ovat omiani. 
siitä, miten MATTA-rakennetta on puhutussa kielessä, erityisesti suomen murteissa, käytetty. Itse keksityt lauseet puolestaan soveltuvat hyvin analyysiin tarvittavien käsitteellisten peruserojen havainnollistamiseen. Korpusesimerkkien ohessa ilmoitan lähdetiedot; sepitetyissä esimerkeissä ei ole merkintää. Korpushaut koskevat kolmea erityyppistä lähdeaineistoa: Lauseopin arkiston murrekorpusta (LA), Digitaalisen muoto-opin arkiston (DMA) aineistoa sekä Suomen murteiden sanakirjan painettuja osia 1-8 (SMS, väli $a$-kurvottaa). ${ }^{3}$ Kukin aineistolähde on alkujaan laadittu eri käyttötarpeisiin: Lauseopin arkisto murteiden lauseopilliseen tutkimukseen, Digitaalinen muoto-opin arkisto murteiden morfologian kokoelmaksi ja Suomen murteiden sanakirja murresanakirjaksi. Näitä korpuksia voi kuitenkin käyttää sikäli yhteismitallisesti, että niiden murreaines on kerätty suhteellisen yhtenäisen aikajakson sisällä, 1920-1960-lukujen aikana (ja DMAaineistoa aina 1990-luvulle asti). Ne edustavat toisiaan täydentäen puhutun suomen murteita ennen Suomen nopeaa kaupungistumista ja murteiden voimakasta tasoittumista.

Kohdistan huomioni MATTA-rakenteen analyysissa paikalliseen kontekstiin ja tässä erityisesti sellaisiin lausetta vastaaviin jaksoihin, jotka koostuvat pääsääntöisesti finiittiverbistä, eri määristä sen argumentteja ja muista tähän lauseeseen liittyvistä lauseenjäsenistä. Teoreettisena taustana toimii väljästi kognitiivinen kielentutkimus, erityisesti konstruktiokielioppi (esim. Fried \& Östman 2004; Hilpert 2014; Goldberg 1995) ja kehyssemantiikka (esim. Fillmore 1985; Lindén, Haltia, Luukkonen, Laine, Roivainen \& Väisänen 2017).

Taulukko 1 tiivistää kustakin korpuksesta löydettyjen $m A t t A$-infinitiivin eri käyttötapojen lukumäärät. Nämä ovat aineistossa selvästi erottuvia ja usein toistuvia infinitiivin esiintymiä, joiksi luen verbiliittomaiset rakenteet (esim. olla jä̈̈ä jättää tekemättä) sekä infinitiivin esiintymisen finiittiverbillisen lauseen adjunktina (MATTArakenne). Taulukon 1 kohta "muut" käsittää sellaiset tapaukset, joissa tekstikontekstia ei ole riittävästi tai joissa infinitiivit ovat selviä leksikaalistumia (esim. välttämäti, lakkaamata, lukkuunottamata, huolimata) tai jotka ovat esimerkiksi finiittiverbittömiä sananlaskuja (esim. mikä elämätä, se näkemätä, SMS, Lavansaari, s.v. elää).

Tiedetään, että MATTA-rakenne ei ole järin taajakäyttöinen verrattuna muihin infinitiivirakenteisiin sen enempää murteissa kuin kirjoitetussa yleiskielessäkään. Laskelmat Lauseopin arkiston korpuksesta osoittavat rakennetta esiintyvän 0,15 kertaa tuhatta sanetta kohden murteissa ja vastaavasti 1,38 kertaa yleiskielessä (ks. Herlin, Leino \& Visapää 2005: 17). Esimerkiksi murreaineistoissa se jää kauas TA-infinitiivin lyhyen muodon (6,72/100o sanetta), MA-infinitiivin illatiivin (5,73/10oo sanetta) ja vielä TE-infinitiivin inessiivinkin (o,43/100o sanetta) taa (mp.). Murteiden ja yleiskielen frekvenssierot selittyvät yleiskielen runsailla leksikaalisilla esiintymillä (Ikola, Palomäki \& Koitto 1989: 347-348). Lauseopin arkiston aineiston perusteella murteissa sitä esiintyy eniten savolaismurteissa ja vähiten lounaismurteissa (mts. 346). Lisäksi taulukosta 1 ilmenee, että MATTA-rakenne eli infinitiivin adjunktikäyttö, joka on tämän tutkimuksen varsinaisena kohteena (kehystetty rivi), muodostaa noin kolmanneksen kai-

3. Lauseopin arkiston murrekorpus ja Digitaalinen muoto-opin arkisto ovat nykyisin vapaasti käytettävissä KORP-palvelussa osoitteessa https://korp.csc.fi/. Suomen murteiden sanakirja on käytettävissä osoitteessa http://kaino.kotus.fi/sms/, mutta sanakirjan painetut osat 1-8 liitetään verkkoversioon takautuvasti. 
kista hakutuloksista. Huomattavaa on, että vaikka vain Lauseopin arkiston korpus on juoksevaa tekstiä ja tässä ainoa pätevä tilastollisen analyysin lähde, on adjunktikäyttöjen ja muiden MATTA-infinitiivin käyttötapojen suhde Digitaalisessa muoto-opin arkistossa ja Suomen murteiden sanakirjassa kuitenkin samaa suuruusluokkaa kuin Lauseopin arkiston aineistossa.

\section{Taulukko 1.}

$m A t t A$-infinitiivit eri rakennetyypeissä korpuksittain. ${ }^{4}$

\begin{tabular}{l|c|c|c|c} 
Rakenne/Korpus & LA & DMA & SMS & Yhteensä \\
\hline olla + MATTA & 34 & 502 & 285 & 821 \\
\hline jäädä + MATTA & 38 & 366 & 91 & 495 \\
\hline jättää + MATTA & 7 & 74 & 34 & 115 \\
\hline heittää + MATTA & 3 & 16 & 16 & 35 \\
\hline muut & 9 & 98 & 25 & 132 \\
\hline $\begin{array}{l}\text { MATTA-rakenne } \\
\text { (adjunkti) }\end{array}$ & 39 & 398 & 275 & 712 \\
\hline Yhteensä & $\mathbf{1 3 0}$ & $\mathbf{1 4 5 4}$ & $\mathbf{7 2 6}$ & $\mathbf{2 3 1 0}$ \\
\hline
\end{tabular}

Kuten taulukosta 1 nähdään, valtaosassa hakutuloksia MATTA-infinitiivi muodostaa verbien olla, jäädä, jättää ja heittää kanssa verbiliiton (ks. esim. 3a-d). Nämä jäävät tämän tutkimuksen ulkopuolelle, sillä ne eivät kuvaa tekemisen tapaa. Rakennetta olla + MAтTA-infinitiivi (esim. 3a) on perusteltu esimerkiksi infinitiivillisissä rakenteissa kieltoverbillisen kiellon puutteella (esim. Meitä kehotettiin olemaan välittämättä mutta ${ }^{*}$ Meitä kehotettiin olemaan ei välittää; ISK $2004 \$ 1627$ ). Esimerkkien $3 \mathrm{~b}-\mathrm{d}$ tilanteet ovat semanttista sukua toisilleen: jättää heittää + MATTA-infinitiivi ovat transitiivisia vastineita esimerkin $3 \mathrm{~b}$ tapaisille intransitiivisille jäämistilanteille. Verbiä heittää on käytetty lähinnä itämurteissa, paikoin myös eri pohjalaismurteiden alueella.

(3) a. tossakin on viäläkin kain ne petäjät mätänemätik (LA, Renko) ${ }^{5}$

b. se jäi nyv viä sanomatakkis se asia (DMA, Kankaanpää)

c. paha on kylyvämätäm maitaaj jättää (DMA, Teisko)

4. Hakulausekkeet kustakin korpuksesta ovat seuraavat: LA-aineisto on saatu vanhamuotoisesta LAXkorpuksesta hakulausekkeella <XPath://cl[w[@pos='v' and contains(@mrp,'inf3') and contains(@mrp, 'abe') and @fun='advl:v']]/ancestor-or-self::s>. DMA-aineisto on poimittu signumista 753. SMS-aineisto on haettu säännöllisillä lausekkeilla .*matta|.*mättä ja .*mata|.*mätä ja .*matik|.*mätik. Murteissa allomorfiaa on runsaasti, mutta en ole SMS:n osalta kerännyt niistä kaikkia (esim. variantteja -mAt, -mAti), koska aineistoa on kertynyt riittävästi muutenkin ja toisaalta morfofonologinen vaihtelu sinänsä ei ole ollut olennaista. Käyttämäni SMS:n säännölliset lausekkeet kattavat merkittävän osan (myös esim. rajageminaatalliset -mAtA ${ }^{x}$-tapaukset) MATTA-rakenteen murteellisista esiintymistä (ks. Pantermöller 2010b: 199-215).

5. Kaikista korpusesimerkeistä on poistettu diakriitit ja erikoismerkit, sillä ne eivät vaikuta tässä artikkelissa esitettyyn syntaktis-semanttiseen analyysiin. 
d. Niih harviaeskeettoo kun sikarokkoo ee soa heettee ['jättää] syömätä olpa vaekka kuin kiire (SMS, Iisalmi, s.v. harviaiskeitto)

Kuten todettua, tämän tutkimuksen kannalta aineiston relevantein osa näkyy lukumäärinä taulukossa 1 kohdassa "MATTA-rakenne (adjunkti)". Esitettyjä tutkimuskysymyksiä ajatellen huomionarvoista on, miten ja mitä adjunktina toimiva MATTArakenne kieltää lauseessa. Tähän keskityn alaluvussa 3.3. Ennen sitä on kuitenkin syytä avata kiellon ja kielteisyyden merkitystä yleisesti, sillä se on olennainen tekijä MATTArakenteen tulkinnassa. ${ }^{6}$ Tätä käsittelen seuraavaksi.

\section{Yleisesti kiellosta, abessiivista ja MATTA-infinitiivistä}

Suomen sijajärjestelmässä abessiivi lukeutuu niin kutsuttuihin vajaakäyttöisiin tai marginaalisiin sijamuotoihin (ISK $2004 \$ 1261$ ). Sen käyttötaajuus on niin kirjoitetussa kuin puhutussakin kielessä pieni (ISK $2004 \$ 1227$; Ikola, Palomäki \& Koitto 1989: 346355; Ikola 1996). Nominiin liittyvänä sijana abessiivilla on minimiparilauseiden valossa yhteys instruktiiviin ja adessiiviin (esim. 4a, vrt. infinitiivien osalta esim. 2) sekä komitatiiviin (esim. 4b). Ajatus vastaa Ison suomen kieliopin (2004§515) esitystä kielteisestä vastineisuudesta infinitiivimuodoissa: abessiivia voi pitää adessiivin, instruktiivin ja komitatiivin negatiivisena vastinparina. ${ }^{7}$

(4) a. Hän teki sen käsin käsillä käsittä.

b. Hän tuli kirjoineen kirjoitta.

Kuten esimerkistä 4a nähdään, (instrumentatiiviset) instruktiivi- ja adessiivi-NP:t kuvaavat tässä väljästi ilmaisten sitä, minkä avulla, mitä välineenä käyttäen tai miten jokin asia tehtiin, ja abessiivi-NP kuvaa tällaisen välikappaleen puuttumista (ks. instrumentatiivisuudesta Jääskeläinen 2004). Samoin esimerkissä 4b komitatiivi kuvaa ilmaistun toiminnan yhteydessä esiintyvää NP:tä (ks. Sirola-Belliard 2016) ja vastaavasti abessiivi tällaisen NP:n puuttumista.

Syntaktista minimiparisuutta väljempää funktionaalista, eri rakennetyyppien keskistä semanttista yhteyttä voi nähdä myös suhteessa nominatiiviin ja partitiiviin. Esimerkit $5 \mathrm{a}-\mathrm{b}$ eivät ole keskenään muodollisia minimipareja, mutta esimerkin $5 \mathrm{~b}$ voi tulkita edustavan semanttisesti kieltoa, jossa abessiivin ilmaisema 'ei ollenkaan ruokaa' toimii kielteisenä parina esimerkin 5a nominatiivin 'kaikki ruoka' tai partitiivin 'jonkin verran ruokaa' tulkintojen kanssa.

6. Perusteellisen selonteon abessiivista lähinnä morfofonologiselta kannalta murteiden ja kirjakielen kehittämisen valossa antaa Pantermöller (2010a, 2010b).

7. Adessiivilla, instruktiivilla, komitatiivilla ja abessiivilla on vielä kullakin läheinen merkitysyhteys erilaisiin adpositiorakenteisiin: jnkn avulla (adessiivi, instruktiivi), jnkn kanssa (komitatiivi, ks. SirolaBelliard 2016), jtakn ilman (abessiivi, ks. Pantermöller 2010b). 
(5) a. Syö sitten ruoka ruokaa.

b. Ole sitten ruoatta. ('älä sitten syö ruokaa')

Esimerkit 5a-b havainnollistavat, miten abessiivi edustaa kieliopillisiin sijoihin vertautuessaan semanttisesti totaalista puuttumista suhteessa partitiivin vajaaseen määrään (ks. Toivainen 1985) ja nominatiivin koko määrään. Kvantitatiivisen määräisyyden suhteen abessiivin voi ajatella muodostavan näiden rakenteiden tulkinnassa semanttisen parin nominatiivin kanssa: nominatiivi kuvaa jäännöksettömästi koko tarkoitetta, abessiivi jäännöksettömästi koko tarkoitteen puuttumista. Vastaavasti partitiivin kanssa semanttinen yhteys syntyy vajauden suhteen: partitiivi kuvaa jotakin maksimiin yltämätöntä määrää tai jonkin määrän puuttumista maksimista (vajautta) ja abessiivi määrän tai tarkoitteen puuttumista kokonaisuudessaan. ${ }^{8}$

Kuten jo esimerkeistä 4-5 huomaa, abessiivin voi nähdä toimivan merkitykseltään kielteisenä vastinparina melko erilaisille sijamuodoille. Marginaalisesta käytöstään huolimatta sillä on siis näin negaation synnyttämiä semanttisia yhteyksiä moniaalle suomen sijajärjestelmässä. Abessiivin yhteisenä semanttisena nimittäjänä voidaan pitää karitiivisuutta, sijamuotoon kiinnittyvän sanavartalon kuvaaman tarkoitteen puuttumista (vrt. ilman jotakin). Mutta mikä saa intuitiivisesti ajattelemaan, että abessiivinen rakenne olisi jollain tavoin yhteydessä muihin kieliopin rakenteisiin, kuten infinitiiveihin (ISK $2004 \$ 515$ )? Nähdäkseni tämä perustuu olennaisesti kielteisyyden ja myönteisyyden keskinäiseen käsitteelliseen implikaatiosuhteeseen.

Filosofisesti kiellon (negaation) voi yleisesti ajatella sisältyvän edellytyksenä jokaiseen positiiviseen esitykseen: kun jonkin väitetään olevan jotakin, se välttämättä jossakin erikseen mainitsemattomassa suhteessa on olematta kaikkea muuta (Horn 2001: xiii). Tällainen epäspesifi olemattomuus jää käsitteellisesti positiivisesti ilmaistun taustalle. Toisin päin tarkastellen kielto implikoi vahvasti kielletyn asian, ominaisuuden tai asiaintilan. Tämä kumpuaa siitä, että tyypillisesti puhutaan odotuksenmukaisemmin siitä, mikä on, kuin siitä, mikä ei ole (vrt. Mihin sinä et jättänyt hansikkaitasi?). (Ks. esim. Givón 1979: 103, 107, 137-138.) Kielto on tunnusmerkkistä, ja se implikoi tai käsitteellisesti edellyttää myönteisyyttä.

Kognitiivisessa kielentutkimuksessa erityisesti kognitiivinen kielioppi esittää negaation kuvaaman käsitteistyksen kompleksisena kohtauksena (complex scene, ks. Langacker 1987: 141-146). Tällainen ei ole kuvattavissa yhtenä yhtenäisenä muodostelmana (ks. erit. Langacker 1991: 132-141; 2008: 59; esim. jäädä-verbistä Huumo 2007). Kuvio 1 (seur. sivulla) havainnollistaa Langackerin (1991: 133-134) käsitystä negaatiosta yleisesti. Siinä negaation implikoima positiivinen tilanne muodostaa taustan ja vertailukohdan (katkoviivallinen laatikko), jossa on jokin entiteetti (olio, atemporaalinen relaatio tai prosessi, ks. Langacker 1987) mentaalisessa tilassa (M). Predikaation aktiivisessa rakenteessa enti-

8. Perinteisesti spesies on fennistiikassa liitetty nimenomaan subjekti- ja objekti-NP:iden semantiikkaan (ks. esim. Vilkuna 1992: 1-6; ISK 2004 \$ 1421). Nähdäkseni (kvantitatiivinen) määräisyys on kuitenkin käsitteellisesti relevantti myös abessiivin kannalta: Hän ei ollut aivan ruoatta 'hän söi ainakin jonkin verran ruokaa jotakin ruokaa'. 
teetti ei esiinny M:ssä (korrespondenssiviiva M:ien välillä). Negaatio siis profiloi entiteetin puuttumisen м:ssä vertailukohtanaan implikoitu positiivinen tilanne M:ssä.

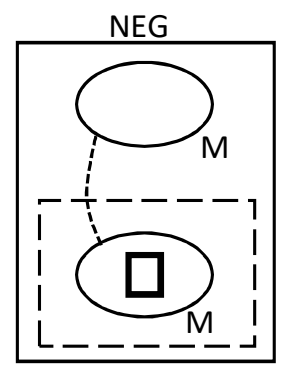

Kuvio 1.

Negaation kuvaama predikaatio Langackerin (1991: 134) mukaan.

Kieltoilmausten kytkös myönteisiin muotoihin näkyy usein jo rakenteiden morfosyntaksissa. Kiellon morfosyntaktisia ilmentymiä voi jakaa eri tavoin. Keskeisin jako käy kieltosanan ja erilaisten kieltoaffiksien kesken. Suomen kieltosana ei (imperatiivissa äl-) on persoonamuodossa taipuva verbi, ja se toimii lausekielloissa. Kieltolause eroaa vastaavasta myöntölauseesta vain leksikaalisen verbin muodon (ns. konnegatiivi) ja kiellon saattoilmiöiden (esim. partitiiviobjekti) osalta: Hävitän hansikkaani vs. En hävitä hansikastani. Yksinkertaisten deklaratiivilauseiden kieltoa kutsutaan typologiassa standardikielloksi (esim. Miestamo 2005; Miestamo, Tamm \& Wagner-Nagy 2015: 13-22).

Muut kiellon lajit jäävät tyypillisesti standardikiellon ulkopuolelle, ja ne edustavatkin (typologisesti) erilaisia erikoisnegaation lajeja. Suomessa affiksaalisia kieltoja ovat prefiksaaliset epä- (esim. epämukava) ja ei- (esim. ei-kotimainen). Edellinen on kontraarinen ja jälkimmäinen kontradiktorinen (Horn \& Wansing 2017: luku 1.4). Käytössä ovat myös suffiksaaliset abessiivi (esim. rahatta) ja adjektiivisiin partisiippeihin liittyvä karitiivijohdin -mAtOn (esim. harkitsematon) (Cannelin 1930). Typologisesti MATTArakenteen tapaiset kielteiset ei-finiittiset muodot ovat ilmeisen harvinaisia, mutta niitä on kuitenkin suomen lisäksi useissa muissa uralilaisissa kielissä, kuten virossa, eteläsaamessa, marissa ja selkupissa (König 1995: 82-83; Miestamo, Tamm \& Wagner-Nagy 2015: 21; Vilkuna 2015: 464-468).

Morfosyntaktisten ilmaisukeinojen lisäksi kieltoon liittyy erilaisia semanttisia ilmiöitä, joihin kuuluvat kieltohakuisuus tai kiellon implikaatio. Sellaiset sanat kuin tuskin, ilman, tippaakaan, likimainkaan, enää, häävi, kummoinen, hennoa ja huolia, joita on niin nomineissa, adpositioissa, adverbeissa kuin verbeissäkin, hakeutuvat eri voimakkuuksin kielteisiin yhteyksiin (esim. en henno luopua siitä, vrt. hennoin vain vaivoin luориа siitä). Vahva kieltohakuisuus mahdollistaa myös kieltoverbittömyyden (esim. mä mitään tehnyt, ks. Kotilainen 2007). Monet tällaiset sanat muodostavat myönteisyyden ja kielteisyyden kesken vaihtelevia polaarisia pareja (autokin vs. autokaan; vielä ehtii vs. enää ei ehdi).

Kun tarkastellaan aineiston valossa tarkemmin itse MATTA-rakenteen kielteisyyttä, käy rakenteen kahtalainen luonne lause(ke)- ja sanakieltona ilmeiseksi. Koska abessiivi on suffiksi, se kiinnittyy MATTA-rakenteessa infinitiivin alivartaloon ja tulee näin kiel- 
täneeksi aina ainakin verbin kuvaaman toiminnan (esim. 6a-b). Tämä on sanakieltoa. Mikäli kuitenkin infinitiivillä on omia lauseenjäseniä kuten esimerkissä $6 a$, abessiivinen kielto vaikuttaa esimerkiksi objektiin sen partitiivisuutena ja muuna kieltohakuisuutena aivan kuten finiittirakenteissakin (vrt. ilman että sanoi amenta). Tämä on lausekieltomaista. Lausekiellosta MATTA-rakenne kuitenkin eroaa siten, että abessiivisen kiellon vaikutusalaa ei voi ilmeisesti infinitiivirakenteen sisällä säädellä samalla tavoin kuin finiittilauseissa ei-sanan paikanvaihdolla (esim. Ei Keijo syönyt asemalla [vaan ehkä joku muu] ja Keijo ei syönyt asemalla [vaan ehkä jossain muualla]).

(6) a. se lähti amenta sanomata (SMS, Nivala, s.v. aamen)

b. valettelemattakim pärjäis kyl (DMA, Honkilahti)

Abessiivikiellon syntaktinen vaikutus ei myöskään ulotu infinitiivirakenteen ulkopuolelle finiittirakenteeseen niissä tapauksissa, joissa finiitti- ja infinitiivirakenteilla on jokin sama lauseenjäsen, joka on tulkittavissa MATTA-rakenteen objektiksi. Esimerkissä 7a pronomini se on finiittirakenteen (se oli sualaantunut) subjekti. Samalla se kuitenkin edustaa tai se tulkitaan myös MATTA-rakenteen keittämäti objektiksi (vrt. [sitä ${ }_{\mathrm{i}}$ ] keittämäti se $_{\mathrm{i}}$ oli sualaantunut). ${ }^{9}$ Abessiivin kielto ei kuitenkaan vaikuta MATTArakenteen ulkopuolelle, finiittirakenteen subjektin muotoon (vrt. ${ }^{*}[\text { keittämäti }]_{\mathrm{INF}}[$ sitä oli sualaantunut $]_{\mathrm{FIN}}$ ). ${ }^{10}$ Samoin esimerkissä $7 \mathrm{~b}$ pronomini ton on finiittiverbin (totaali-) objekti, joka edustaa myös infinitiivin objektia mutta jonka muotoon MATTA-rakenne

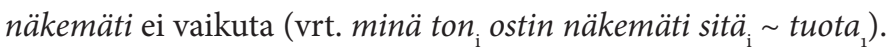

(7) a. niin keittämätis se oli sualaantunut talvej ja se oli sitte hyvvää (LA, Vampula)

b. se- oli neljä vuarev vanha kom minä ton- ostin näkemätit Tampereella (LA, Suodenniemi)

Sekä kieltoverbi että abessiivi ilmaisevat molemmat negaatiota (ks. kuviota 1), mutta niiden syntaktisessa käyttäytymisessä ja semantiikassakin on merkittäviä eroja. Toimiessaan adjunktina MATTA-rakenne ilmentää nimenomaan infinitiivillä kuvatun toiminnan puuttumista finiittirakenteella kuvatun toiminnan yhteydestä. Tähän palaan tarkemmin luvussa 4.

Erilaisten kieltomuotojen keskinäisestä vuorovaikutuksesta voidaan havaita, että murteissa prepositio ilman esiintyy usein MATTA-rakenteen kanssa: esimerkiksi Kohvpantka [kahvitölkki] kans on ummistettu nii tiukkua jot ei aukiikua ilma kankiimatta (SMS, Metsäpirtti, s.v. kangeta; ks. myös Vihervalli 2016: 68). Prepositio ja abessiivi eivät kumoa toisiaan. Sama pätee myös nomineihin, esimerkiksi ilman hatutta 'ilman hattua' (ks. Pantermöller 2010b: 17-27). Sen sijaan kieltoverbi kumoaa MATTA-rakenteen abes-

9. Parafraasiksi ei sovi *sen keittämäti se oli sualaantunut, koska abessiivi laukaisee objektissa kiellon partitiivin infinitiivirakenteen sisällä (po. sitä).

10. Toisenlainen syntaktinen jäsennys kävisi: [keittämäti sitä] [ $\varnothing_{\mathrm{i}}$ oli sualaantunut]. 
siivin kiellon, sillä verbin vaikutusala ulottuu adverbiaaliin. Näin esimerkki 8a on väljästi samamerkityksinen myönteisen ilmaisun kanssa (vrt. näet se menee ajamalla). Pragmaattisesti ne ovat kuitenkin erimerkityksisiä. Esimerkin 8a tapauksessa MATTA-rakenne tuntuu ilmaisevan myös konditionaalista suhdetta finiittirakenteeseen (vrt. eihän se mene, jos ei aja). Ilman erikseen lisättävää ehtoon viittaavaa ainesta myönteinen muoto ei vaikuta samaan tapaan konditionaaliselta (vrt. näet se menee vain, jos ajaa).

(8) a. se [lehmä] on sellaine juutikka, niet eihä se meä ajamatta mihikeä (SMS, Kurkijoki, s.v. juutikka)

b. En tullut uiden/uimalla Tulin uimatta [ei: 'uin']

c. Tulin uiden/uimalla En tullut uimatta [kyllä: 'uin (ainakin jonkin verran)']

Esimerkeillä 8b-c havainnollistan sitä, että vaikka pelkästään negaation kannalta tarkastellen myönteiset ja kielteiset ilmaukset olisivatkin jossain määrin samamerkityksisiä, niin negaation ilmaustyypillä on kuitenkin vaikutuksensa ilmaistun toiminnan "kvantifikaatioon" tai esiintyvyyteen. Esimerkissä 8b uimisen lausekielto koskee tulemista kokonaisuudessaan, mutta MATTA-rakenteen merkitykseen sisältyy lisäksi implikaatio, että uimista ei tapahtunut ollenkaan, vähäisessäkään määrin. Selvemmin tämä tulkinta käy ilmi (käänteisesti) esimerkin 8c MATTA-rakenteellisessa lausekiellossa, joka implikoi, että tulemiseen sisältyi ainakin jossain määrin myös uimista jonkin muun mainitsemattoman ja mahdollisen liikkumistavan lisäksi (vrt. en tullut kokonaan uimatta). Jälleen myönteinen ilmaustapa käsittää tulemisen niin, että se tapahtui kokonaisuudessaan uimisena.

Tämä käsitteellinen ero liittynee siihen, että lausekiellossa ei toimii propositionaalisena kieltona kieltäen totaalisesti vaikutusalaansa kuuluvat asiat. Vastaavasti abessiivi kieltää vain infinitiivin (tai nominin) ilmaiseman asian, ja sen itsensä merkitystulkintaan - kvantifikaatioon, määrään ja esiintyvyyteen - voi vaikuttaa finiittirakenne. Tässä suhteessa abessiivi asettuu nominatiivin (koko määrä) ja partitiivin (vajaa määrä) yhteyteen siten, että abessiivi kuvaa itse puuttuvaa osaa, joka perustyyppisesti on totaalista (puuttuminen kokonaan), mutta se voi olla myös osittaista (vaje). ${ }^{11}$

Kuten todettua, lähtökohtanani on se Ison suomen kieliopin (2004\$515) käsitys, että MATTA-rakenne olisi TEN- ja MALLA-rakenteiden kielteinen vastine. Myös esimerkkien $8 \mathrm{~b}-\mathrm{c}$ parafraasit perustuvat tähän intuitiiviseen kytkökseen. Tähän tulkintavaihtoehtoon

11. Abessiivin epätyypillisempää vajaamääräistä puuttumista ja ylipäänsä liittämistä definiittisyyteen ja kvantifikaatioon kuvaa seuraava Helsingin Uutisten (Nurmi 2017) kirjoitus otsikolla "Yksinhuoltajaäiti sinnitteli rahatta kolme viikkoa - kieltäytyi lähtemästä Kelan konttorista":

Juuri opinnoistaan valmistunut alle 30-vuotias Emilia (nimi muutettu) oli käytännössä ilman rahaa

kolmisen viikkoa. - Se oli ahdistavaa. Olin täysin rahaton ja toimeentulotuen armoilla. En pystynyt

hakemaan työttömyyspäivärahaakaan, koska en ole vielä saanut paperia valmistumisestani. Opiskelu-

aikana hän oli saanut työmarkkinatukea. Pärjäämistä helpottivat läheiset, jotka lainasivat rahaa

9-vuotiaan lapsen äidille.

Käy ilmi, että Emilia ei ollut käytännössä täysin rahatta vaan hän oli elänyt ilman puuttuvaa perustoimeentuloksi katsottavaa osaa. Samankaltainen tulkintaero on nähtävissä myös adessiivin ja abessiivin välillä: en saa lippua [hallussani olevalla tällä] rahalla vs. en saa lippua rahatta, so. 'ilman puuttuvaa osaa lipun hinnasta'. (Lihavoinnit MH.) 
palaan tarkemmin luvussa 3. On kuitenkin syytä vielä motivoida tämän ajatellun kytköksen perustumista negaation yleiseen implikaatioon. Kuten edellä on jo havainnollistettu, kielteisillä ilmauksilla on usein selvä yhteys myönteisiin ilmauksiin jo rakenteellisella tasolla. Kielteiset ilmaukset ovat tyypillisesti morfologisesti tunnusmerkkisiä. Erityisesti käsitteellinen kytkös on ilmeinen (ks. Langacker 1991: 132-141). Tämä näkyy myös esimerkiksi kiellon ja modaalisuuden suhteesta: Modaalisille ilmauksille voi usein esittää myönteisen ilmauksen kanssa olennaisesti samaa merkitseviä kielteisiä ilmaustapoja (esim. en voi uida minun täytyy olla uimatta 'en ui'). Vastaavasti myönteisille ilmauksille on päinvastaisia kieltomerkityksisiä ilmauksia. Nämä voivat olla kontraarisia (sinun täytyy uida 'pitää vs. sinun täytyy olla uimatta 'et voi') tai kontradiktorisia (esim. sinun täytyy uida vs. voit olla uimatta 'ei ole pakko'). (Ks. esim. ISK $2004 \$ 1613$.) Juuri myöntö- ja kieltomuotojen erilaiset kontraariset (skalaariset) ja kontradiktoriset (dikotomiset) vastakohtasuhteet kytkevät ne käsitteellisesti toisiinsa sen lisäksi, että kielto implikoi myönteisyyttä käsitteelliseksi taustakseen.

Tämän artikkelin kannalta keskeisenä teoreettisena huomiona kielteisyydestä voi pitää sitä, että kiellon käsiterakenne edellyttää taustakseen myönteisyyttä. Kielto on käsitteellisesti dependentti (ks. Langacker 1991: 132). Tätä ajatusta avaan seuraavissa analyysiluvuissa, joissa kuvaan MATTA-rakennetta kahdesta eri lähtökohdasta. Luvussa 3 tarkastelen rakennetta infinitiivijärjestelmän omana kieltomuotona, jolloin sen ja TEN- ja MALLA-rakenteet voi nähdä lähikonstruktioiden ryhmänä (vrt. ISK $2004 \$ 515$ ). Luvussa 4 esitän kehyssemantiikkaan tukeutuvan konstruktiokieliopillisen formalisoinnin MATTA-rakenteesta kokonaisuudessaan.

\section{TEN-, MALLA- ja MATTA-rakenteet lähikonstruktioiden ryhmänä}

Luvussa 3 havainnollistan, miten MATTA-rakenne toimii TEN- ja MALLA-rakenteiden vastineena. Ensin alaluvussa 3.1 esitän kaksi infinitiivijärjestelmän hahmotustapaa, sitten (3.2) käyn läpi TEN- ja MALLA-rakenteiden päämerkitykset ja lopuksi (3.3) esitän kaikkien kolmen rakenteen keskinäiset yhteydet lähikonstruktioina.

\subsection{Infinitiivijärjestelmän kaksi jäsentämisperiaatetta}

Kuten olen edellä todennut, Isossa suomen kieliopissa (2004\$515) esitetään, että MATTArakenne on merkitykseltään vähemmän spesifinen kuin TEN- ja MALLA-rakenteet ja että se toimisi näiden kahden infinitiivirakenteen kielteisenä vastineena. Luvussa 2 olen osoittanut kiellon myöntöä implikoivia piirteitä. Niitä ovat kiellon morfologinen tunnusmerkkisyys, usein kiellon myöntömuodosta derivoituva rakenne (esim. mukava $\rightarrow$ epämukava), kiellon ja myönnön käsitteellinen kytkös ("vastineisuus") kontraarisuuden ja kontradiktorisuuden varaan rakentuvissa vastakohtasuhteissa sekä ennen kaikkea negaation yleinen käsiterakenne (ks. kuviota 1).

Tässä luvussa pitäydyn Ison suomen kieliopin (2004 \$515) luonnehdinnassa korostaen sitä, että infinitiivirakenteita on mahdollista tarkastella myös suomen infinitiivijärjestelmän sisällä keskenään eri tavoin kytköksissä olevina konstruktioina. Maksi- 
maalisimmin tätä ajatustapaa edustaa Leino (2003: 99-111 mm. Siron 1964 pohjalta), joka esittää, että kaikki suomen infinitiivirakenteet järjestyvät yhden, suhteellisen abstraktin INFINiTıIVI-konstruktion alle (ks. mts. 105, kuvio 19). Spesifimmät yksittäiset infinitiivirakenteet (esim. TA-infinitiivin lyhyt muoto, syödä, juoda, juosta) perivät tuon skemaattisen infinitiivikonstruktion ominaisuudet mutta lisäävät siihen myös omaa merkitystään. Infinitiivimuotojen käyttöympäristöt ovat usein kuvattavissa infinitiivirakenteina tai -konstruktioina (esim. PERMIssIIvi-konstruktio, annan Keijon syödä pihvin), jotka vastaavasti perivät yksittäisen infinitiivimuodon ominaisuudet. Leinon mukaan infinitiivimuotoja (esim. TA-inf. lyhyt muoto, MA-inf. adessiivi, TE-inf. inessiivi) käytettäessä motivoituu aina siis ainakin kolme infinitiivikonstruktiota (ks. mts. 11o, kuvio 22)..$^{12}$ Tällä tavoin hahmoteltu infinitiivijärjestelmän yhtenäisyys perustuu (vertikaalisiin) skemaattisuussuhteisiin.

Toinen, vaihtoehtoinen infinitiivikonstruktioiden tarkastelutapa, joka ei sulje edellistä pois, perustuu eri tavoin läheisten infinitiivi-ilmausten hahmottamiseen lähikonstruktioiden ryhmittyminä. Tällöin yksittäisten infinitiivikonstruktioiden kesken hahmottuu erilaisia rakenteellis-funktionaalisia suhteita ja yhtäläisyyksiä. Tällaisia ovat muun muassa Kotilaisen (2005) tutkimat mikäs on ollessa $\sim$ olla $\sim$ ollakseen -tyyppiset ilmaukset tai Visapään (2008: 29-65) analysoimat itsenäiset [T]A-infinitiivikonstruktiot (esim. syödä siinä sitten $x$, syödä nyt $x$, syödäpä (nyt) $x$ ). Näin tarkastellen saman skemaattisen tason ilmaustyyppien kesken hahmottuu erilaisia horisontaalisia kytköksiä.

Ison suomen kieliopin (2004 $\$ 515)$ esittämä ajatus siitä, että MATTA-rakenne on TENja MALLA-rakenteiden kielteinen vastine, ohjaa tässä tarkastelemaan MATTA-rakenteen suhdetta TEN- ja MALLA-rakenteisiin jälkimmäisen jäsentämisperiaatteen mukaisesti eli pitämään niitä lähikonstruktioina. Nämä infinitiivirakenteet eivät kuitenkaan ole rakenteellisesti toisilleen yhtä läheisiä kuin edellä esittelemäni Kotilaisen (2005) ja Visapään (2008) tutkimat rakenteet. Ne eivät varioi esimerkiksi vaihtelevin infinitiivimuodoin jotain tunnistettavaa "samaa" (idiomaattista) ilmaustyyppiä (vrt. esim. mikäs on INF -rakenne, Kotilainen 2005). Ne ovat kuitenkin kaikki finiittirakenteen adjunkteja ja sikäli samankaltaisia. Lisäksi MATTA-rakennetta voi pitää infinitiivijärjestelmän sisällä kieltomuotona - kielteisyyttähän ei muuten voi ilmaista infinitiivirakenteissa. Myös kiellon myöntöä taustanaan implikoiva käsitteellinen piirre johtaa kysymään, mitkä voisivat olla (adjunktina toimivaan) MATTA-rakenteeseen verrattavia myönteisiä infinitiivikonstruktioita. Koska lähikonstruktioiksi ei hahmotu yksinomaan rakenteellisesti läheisiä infinitiivi-ilmaisuja, on yhdistävänä piirteenä pidettävä merkitystä. Tällaisena voidaan pitää erilaisia tavan merkityksiä väljässä mielessä.

\subsection{Tavan merkityksistä infinitiivirakenteissa}

Tapaa väljästi kuvaavia infinitiivirakenteita ovat siis TEN- ja MALLA-rakenteet. Annan seuraavaksi näiden rakenteiden käytöstä tiiviin yleiskuvan, joka perustuu Hamu-

12. Tarkkaan ottaen Leino (2003: 110) puhuu vain TA-infinitiivin lyhyestä muodosta, mutta ajatus kolmesta konstruktiosta on luonnollisesti sovellettavissa kaikkien infinitiivimuotojen käyttöihin. 
seen (2017: 131-141). Se pohjautuu samoihin korpuslähteisiin kuin tämä artikkeli. Kuvio 2 havainnollistaa yleisesti TEN- ja MALLA-rakenteilla kuvattuja tavan merkityksiä (vrt. mas. 142, taulukko 3). Merkityserottelut perustuvat finiittirakenteen ja infinitiivirakenteen keskinäisten semanttisten tulkintojen yleistyksiin korpusaineistosta.

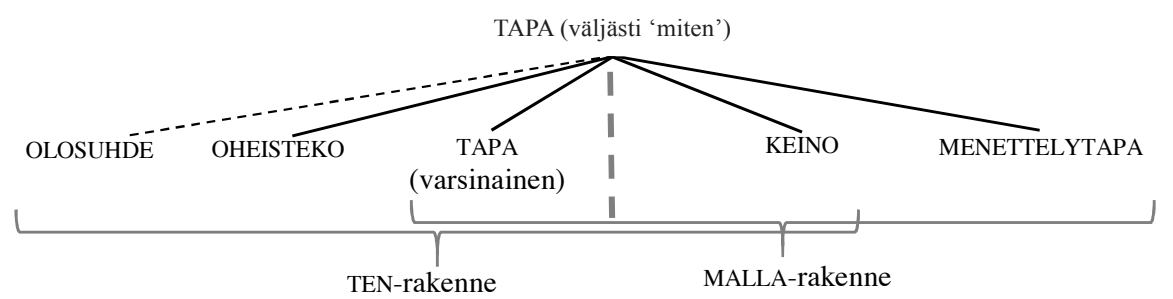

Kuvio 2.

TEN- ja MALLA-rakenteiden tavan merkitykset (Hamunen 2017).

Tapa esiintyy kuviossa kaksi kertaa. Ensinnä tapaa voi pitää väljästi erilaisten verbeillä kuvattavia toimintoja luonnehtivien rakenteiden yhteisenä semanttisena ominaisuutena. Tässä mielessä tavan merkitys ('miten') liittyy mitä moninaisimpiin kielen rakenteisiin ja ilmaustyyppeihin, vaikka kuvio 2 rajoittuukin vain TEN- ja MALLA-rakenteisiin. Paksu katkoviiva jakaa kuvion kahteen osaan toisaalta osoittaen, miten TEN- ja MALLArakenteiden käytön merkitystulkinnat pääasiallisesti jakautuvat aineiston valossa, ja toisaalta korostaen ennen kaikkea varsinaisen tavan ja keinon käsitteellistä eroa.

Toiseksi tapa esiintyy kuviossa yhtenä TEN-rakenteen merkityksistä. Varsinaisella tavalla tarkoitan sellaista TEN- tai MALLA-rakenteen käyttöä, jossa infinitiivin merkitys tarkoittaa samaa toimintaa kuin finiittiverbi, mutta lisäksi infinitiiviverbin leksikaalinen merkitys on "rikkaampi" kuin finiittiverbin. ${ }^{33}$ Adjunktina infinitiivirakenne jäsentyy merkitykseltään juuri finiittirakenteella kuvatun toiminnan tavan luonnehdinnaksi. Tätä käyttöä on sekä TEN- että MALLA-rakenteella (esim. 9a-b, kuvio 2). Vastaavasti keinon MALLA-rakenne (harvemmin TEN) ei kuvaa samaa toimintaa finiittiverbin kanssa eivätkä verbit ole leksikaaliselta merkitykseltään läheisiä (esim. hyponymiasuhteessa). Keinoksi tulkittava infinitiivirakenne kuvaa toimintaa, jonka avulla tai välityksellä finiittirakenteella esitetty tilanne tai tavoite saavutetaan (esim. 10a-b).

(9) a. hyvin se [sairas vanhus] hoeperrellen käveli (SMS, Kajaani, s.v. hoiperrella)

b. se [kihdin vaivaama] niij jäpöittelemällä kävelöö (SMS, Konginkangas, s.v. jäpötellä jäykästä kulkemisesta)

13. Pidän ylipäätään varsinaisen tavan merkityksen ydinalueena sellaisia verbin leksikaalisia merkityspiirteitä, jotka tulevat ilmi verbileksikon hyponymiasuhteissa. Varsinainen tapa on siis erityisesti (verbi-) leksikalisaatioon kuuluva semanttinen dimensio. Suomessa tämä ilmiö havainnollistuu selvästi esimerkiksi liikeverbeissä kuten liikkua 'edetä', kävellä 'liikkua jaloin', hoiperrella 'liikkua jaloin epävarmoin ja horjahtelevin askelin', joissa seuraava verbi kuvaa edellistä juuri liikkumisen tavan suhteen astetta seikkaperäisemmin. Koloratiiviverbit ovat tässä mielessä erityisiä tapaverbejä (Hamunen 2012). Tämä ilmenee myös esimerkeistä 9a-b. 
(10) a. minussa ei oos sitä, sitä, uskova ensikeä, että puhumalla soahaa mikä paranemmaa (LA, Mikkelin mlk)

b. se kuorma ankrausi sinne lietteeseen, sei lähteny pukaten eikä vettäin (SMS, Liminka, s.v. ankraantua verbistä ankkuroitua 'juuttua, takertua')

MALLA- ja TEN-rakenteille enemmän tai vähemmän yhteisten merkitystulkintojen, varsinaisen tavan ja keinon, lisäksi kummallakin infinitiivirakenteella on myös omia käyttöjään. Selvästi erottuva on vain TEN-rakennetta koskeva oheisteon merkitys. Kuten esimerkistä 11 havaitaan, oheisteossa infinitiivi ja finiittiverbi kuvaavat eri toimintoja (vrt. varsinainen tapa, esim. 9a-b), mutta infinitiivin ei voi tulkita kuvaavan keinoa (vrt. esim. 10a-b). Koska finiittiverbi (tul 'tuli') ja infinitiivi (itkiim 'itkien') kuvaavat käsitteellisesti eri toimintoja, ovat samanaikaisia ja kuvaavat saman tekijän (Tilta) toimintaa, ne eivät muodosta vakiintunutta käsitteellistä kokonaisuutta vaan pikemminkin tilanteisen havaintokokonaisuuden (König 1995: 65-66). ${ }^{14}$ Esimerkin 12 olosuhteen infinitiivi menne tulle[n] rajoittuu lähinnä tulla-verbiin (esim. illan tullen). Sitä voi pitää jo hyvin marginaalisena tavan ilmaisemisen kannalta; pikemminkin se on merkitykseltään temporaalinen (ks. kuvion 2 katkoviiva). MALLA-rakenteen keinon merkityksen alalajina voi pitää menettelytapaa, joka käsittää konkreettisten teko- ja valmistamistoimintojen erilaisia valinnaisia menettelytapoja. Esimerkiksi kalan pyytämistä voi harjoittaa monin eri menetelmin: onkimalla, uistelemalla, tuulastamalla tai iskettämällä 'lyömällä puunuijalla' (esim. 13).

(11) ja Tilta tul itkiim meille ja sano että tuota lähe lähet tuota kahtommaa (LA, Leppävirta)

(12) täsä ne aim poikkes mennen tulle (LA, Honkilahti)

(13) ne sillä laella iskettämällä kae niitä [kaloja] ottoa (DMA, Uurainen)

Edellä esitetyn perustella tapaa väljässä mielessä kuvaavien TEN- ja MALLA-rakenteiden keskeiset merkitykset ovat siis varsinainen tapa (TEN ja MALLA), keino (lähinnä MALLA), oheisteko (TEN) ja menettelytapa (MALla) (kuvio 2, ks. tarkemmin Hamunen 2017). Olosuhteen merkitys on marginaalinen. Olennaista näille infinitiivirakenteiden merkityksille on se, että ne kuvaavat temporaalisesti samanaikaista toimintaa finiittirakenteen kanssa. ${ }^{15}$ Varsinainen tavan infinitiivi kuvaa samaa toimintaa kuin finiittiverbi. Kei-

14. Käsitteelliseksi kokonaisuudeksi voi ajatella esimerkkien 9a-b verbien keskenään muodostamaa merkityskokonaisuutta (kävellä, hoiperrella, jäpöitellä). Niissä verbit vaikuttavat toistensa merkitykseen ja kuvaavat samaa toimintaa. Tämä ilmenee myös siten, että esim. koloratiivirakenne (kävellä jäpöittelee, ks. esim. Hamunen 2012) muodostetaan juuri (varsinaisen) tavan suhteen keskenään järjestyvien verbien kesken (hyponymia). Oheisteon infinitiiville näin ei voi tehdä (vrt. esim. 11 *tulla itkee *itkeä tulee). Ns. statusrakennetta voi pitää oheisteon infinitiivinä. Siinä infinitiivirakenne kuvaa hallitsevan rakenteen subjektin jonkin osan toimintaa, esim. meiv väänsin hampaat riuskui ['kirskuen'] kämment (DMA, Somero).

15. Tosin keinon MALLA-rakenteen temporaalisen suhteen finiittiverbiin voi tulkita ajallisesti edeltävästä samanaikaistuvaksi. Keinoa kuvaava toiminta on sitä, mikä johtaa tai minkä avulla saavutetaan finiitti- 
non infinitiivi puolestaan kuvaa eri toimintaa kuin finiittiverbi mutta on kytköksissä sen asiaintilaan keinon merkityksen tavoitteellisen luonteen vuoksi. Toisin kuin tavan tai oheisteon infinitiivi se voi olla myös eritekijäinen kuin finiittirakenne, esimerkiksi juolaheinä ei häviäm muuta kuj järijestään kuokkimalla (DMA, Virrat), jossa 'juolaheinä häviää (ainakin tilapäisesti), kun x kuokkii'. Oheisteon infinitiivi kuvaa eri toimintaa kuin finiittiverbi mutta aina samatekijäistä, ja verbien kuvaamat toiminnat eivät ole riippuvaisia toisistaan tai vaikuta toisiinsa.

\subsection{MATTA-rakenne kontraarisena lähikonstruktiona}

Edellä (3.2) olen antanut yleiskuvan TEN- ja MALLA-rakenteiden väljästi tapaa kuvaavista merkityksistä sekä infinitiivien ja finiittiverbien kuvaamien tapahtumien keskinäisistä suhteista. Tässä alaluvussa tarkastelen MATTA-rakenteesta esitettyä ominaisuutta TEN- ja MALLA-rakenteiden kielteisenä vastineena (ISK 2004 \$515) käyttämällä erilaisia kielitajuun pohjaavia parafraaseja korpusesimerkeistä ja vertaamalla niitä siihen, mitä murteiden TEN- ja MALLA-rakenteiden merkityksistä on edellisessä alaluvussa ilmennyt (ks. tark. Hamunen 2017). ${ }^{16}$

Tarkastelusta voidaan sulkea pois sellaiset leksikaalistuneet MATTA-muodot, jotka ovat irronneet infinitiivimuotojen produktiivisesta paradigmasta ja joita ei näin ollen enää ole mielekästä tai mahdollistakaan verrata TEN- tai MALLA-infinitiiveihin (esim. krohomut niin orottamata ['yllättäen'] pöytähän tryykää (SMS, Isojoki, s.v. krohmu). Niiden verbimäisyys on huvennut, ja ne ovat usein joko adverbistuneita tai muodostavat adpositiomaisia rakenteita, esimerkiksi siitä huolimatta (ks. Ikola, Palomäki \& Koitto 1989: 353). Leksikaalistumina pidän muun muassa lekseemejä huamaamatik, lakkaamata, valehtelemata.

Yksiselitteisimmin MATTA-rakenteelle voi esittää miniparin sekä TEN- että MALLArakenteilla, jotka kuvaavat varsinaista tapaa (esim. 14 ja $\left.14^{\prime}\right) .{ }^{17}$ Samoin molemmat infinitiivit sopivat minimiparilauseisiin keinoa kuvatessaan, vaikka keinon merkitys onkin enemmän MALLA-infinitiivin piirre (esim. 15 ja 15’; Hamunen 2017: 139-140; ks. myös

verbillä kuvattu asiaintila. On odotuksenmukaista, että se usein ainakin aloitetaan ennen hallitsevan rakenteen kuvaamaa toimintaa. Toisaalta taas keinon infinitiivin kuvaaman toiminnan voi tulkita olevan myös osa finiittiverbin kuvaamaa kokonaistapahtumaa, jolloin infinitiivin kuvaama toiminta on ikään kuin hallitsevan rakenteen kuvaaman toiminnan "sisällä". Tällainen mutkistaa verbien kuvaamien tapahtumien keskinäisiä temporaalisia suhteita. Tässä mielessä edellä antamani yleiskuva yksinkertaistaa tulkintoja jonkin verran. (Ks. myös Lappalainen 1993: 99.)

16. MATTA-, TEN- ja MALLA-rakenteiden keskinäisen yhteyden suoraviivaisessa selvittämisessä on sellainen metodinen ongelma, että korpusaineistoista harvoin, jos koskaan, löytyy rakenteiden koko merkitysvaihtelun kattavia minimipareja, joista rakenteiden mahdollisia suhteita voisi suoraan tarkastella. Siksi kielitajun varainen parafraasien käyttö epäsuorana menetelmänä on tässä perusteltua. Kuitenkaan MATTA-rakenteiden parafrasointi TEN- ja MALLA-rakenteiksi ei aina ole eikä voi olla suora ja yksiselitteinen, sillä kuten alaluvussa 3.2 käy ilmi, osa tavan merkityksistä sopii sekä TEN- että MALLA-rakenteelle. Hamusen (2017) mukaan tavan merkitykset näyttävät jakautuvan murreaineistossa vain osin tendenssimäisesti jommallekummalle infinitiivirakenteelle ja joihinkin merkityksiin ja käyttöyhteyksiin sopii sekä TEN- että MALLA-rakenne. Siksi esimerkiksi murrejakaumatkaan eivät tunnu tarjoavan yksiselitteistä ratkaisua jommankumman muodon puolesta.

17. Minimipariesimerkeissä (nro') TEN- ja MALLA-infinitiivimuodot esitetään yleiskielisessä muodossa kenoviivojen välissä. 
Salminen 2003: 31). Ne MATTA-rakenteiset ilmaukset, jotka tuntuvat selvimmin saavan vain MALLA-infinitiivin minimiparikseen, tulkitsen merkitykseltään lähinnä keinon ilmaisuiksi (esim. 16 ja 16'). Menettelytavan merkityksen heikko sopivuus tähän yhteyteen voi juontua siitä, että tuntuisi viestinnällisesti erikoiselta ilmaista jotain tehtävän muttei jollain kokonaisvaltaisella menetelmällä (vrt. esim. 13' ?ne sillä laella /iskettämättä/ kae niitä [kaloja] ottoa). Menettelytavan MALLA-rakenne tuntuukin eroavan keinosta juuri siten, että se vastaa merkitykseltään kokonaisvaltaisesti finiittirakenteen kuvaamaa toimintaa, ei vain - kuten keino - päämäärähakuista osatoimintaa.

(14) ruukaan sanoo, ilmam peittelemätä (DMA, Myrskylä)

(14') ruukaan sanoo /peitellen peittelemällä/

(15) sitähä [kurria] tuli sillo yhtee aikaa ilma tilaamatta näät meijeristä (DMA, Lappee)

(15’） sitähä tuli sillo yhtee aikaa /tilaamalla tilaten/ näät meijeristä

(16) ajattelemata ei pitkällep peästy ennenkään (DMA, Kannonkoski)

(16’) /ajattelemalla/ ei pitkällep peästy ennenkään

Vastaavasti ne MATTA-rakenteet, joiden minimipari lausekontekstissa tuntuu luonnollisimmin olevan TEN-rakenne, saavat tulkinnakseen helposti juuri tälle infinitiiville ominaisia merkityksiä. Näistä selvin on oheisteon merkitys (esim. 17 ja 17'). Toinen, tavan merkitysten ulkopuolelle jäävä käyttö on havainto- ja kognitioverbejä koskevat olosuhteen MATTA- ja TEN-rakenteet, esimerkiksi tietämättään [vrt. tietäen] tek sen (DMA, Sumiainen). Nämä voivat olla myös erisubjektisia hallitsevan rakenteen kanssa, esimerkiksi lehmät söi havattematta [vrt. $x: n$ havaiten 'huomaamatta'] sen tupakkapellon (SMS, Jyykeä, s.v. havaita). Kolmas, ehkä selvimmin erottuva ryhmänsä ovat varsinaiset tavan merkitykset (esim. 18 ja 18').

(17) söivä oikke suremat (DMA, Honkilahti)

(17’) söivä oikke /surren *suremalla/

(18) niin siitä [suksimäestä] mäni lankiiematan niin se (DMA, Nurmes)

$\left(18^{\prime}\right)$ niin siitä mäni /langeten ?lankeamalla/ niin se

Edellä esimerkeillä 14-18 sekä 14'-18' olen havainnollistanut sitä, että MATTAinfinitiivi voi esiintyä minimiparivaihtelussa TEN- ja MALLA-infinitiivien kanssa ja että kaikki kolme infinitiivirakennetta esiintyvät samoissa merkitystehtävissä keskenään. Taulukko 2 tiivistää aineistohavainnot. 
Taulukko 2.

Adjunktina toimivien MATTA-, TEN- ja MALLA-rakenteiden merkitysyhtäläisyydet kielitajun varaisen tulkinnan valossa.

\begin{tabular}{|c|c|c|c|c|c|c|c|}
\hline \multicolumn{7}{|c|}{ MATTA-rakenne, infiniittiset minimiparit ja tavan merkitys (väljästi) } & \multirow{3}{*}{$\begin{array}{c}712 \\
\mathrm{~N}\end{array}$} \\
\hline \multirow[t]{2}{*}{ Tulkinta } & \multicolumn{5}{|c|}{ Merkityspiirre } & \multirow[t]{2}{*}{ Rakenne } & \\
\hline & A & B & C & D & $\mathrm{E}$ & & \\
\hline keino & $+1-$ & $+/-$ & - & + & $+/-$ & $\begin{array}{l}\text { MALLA tai TEN } \\
\text { MALLA } \\
\text { TEN }\end{array}$ & $\begin{array}{r}109 \\
14 \\
5\end{array}$ \\
\hline (varsinainen) tapa & + & + & + & + & $+1-$ & $\begin{array}{l}\text { TEN } \\
\text { MALLA tai TEN }\end{array}$ & $\begin{array}{r}106 \\
99\end{array}$ \\
\hline oheisteko & + & + & - & - & $+1-$ & $\begin{array}{l}\text { TEN } \\
\text { MALLA tai TEN }\end{array}$ & $\begin{array}{r}53 \\
3\end{array}$ \\
\hline menettelytapa & + & + & + & + & $+1-$ & $\begin{array}{l}\text { MALLA tai TEN } \\
\text { MALLA }\end{array}$ & $\begin{array}{l}6 \\
1\end{array}$ \\
\hline \multirow{3}{*}{\multicolumn{3}{|c|}{$\begin{array}{l}\text { Selitykset: } \\
A=+/- \text { samatekijäinen } \\
B=+/- \text { samanaikainen } \\
C=+/ \text { - sama toiminta } \\
D=+/ \text { - teot vaikuttavat toisiinsa } \\
E=+/ \text { - kielteinen }\end{array}$}} & & & & $\begin{array}{l}x: n \text { näkemättä } \\
\text { nähden -tyyppi }\end{array}$ & 37 \\
\hline & & & & & & $\begin{array}{l}\text { MATTA- } \\
\text { leksikaalistuma }\end{array}$ & 55 \\
\hline & & & & & & $\begin{array}{l}\text { muu (rakenne/ } \\
\text { tulkinta) }\end{array}$ & 224 \\
\hline
\end{tabular}

Taulukosta 2 nähdään, että tämän artikkelin korpusaineistona olevat MATTA-rakenteet (712 es.) jakautuvat Rakenne-sarakkeen mukaisesti kahtia siten, että yli puolelle aineiston ilmauksista voi esittää minimiparitoisintoja TEN- ja MALLA-rakenteilla (433 es.). Toinen puoli aineistosta (279 es.) ei tähän sovellu (paksummalla viivalla erotetut solut). Huomionarvoista on ensiksi se, että TEN- ja MALLA-minimiparit kuvaavat nimenomaan väljästi erilaisia tavan merkityksiä, jotka näkyvät Tulkinta-sarakkeessa. Näiden tulkintaan liittyviä tekijöitä on esitetty piirteinä A-E Merkityspiirre-sarakkeessa. Toiseksi silloin, kun piirteen E arvo on [-], kyse on MATTA-rakenteesta, joka eroaa TEN- tai MALLAinfinitiivin sisältävästä minimiparista vain kielteisyyden suhteen (abessiivin merkitys). Tämä todentaa Ison suomen kieliopin $(2004 \$ 515)$ sinänsä perustelemattoman ajatuksen MATTA-rakenteen kielteisestä vastineisuudesta suhteessa TEN- ja MALLA-rakenteisiin.

Taulukosta 2 tulee esittää muutamia varauksia. Ensinnäkin vain valituilla piirteillä A-E ei voi pelkistää eroteltaviksi kaikkia tässä käytettyjä tavan eri merkityksiä (vrt. varsinainen tapa ja menettelytapa). Toiseksi aineiston esimerkeistä kielitajun varassa esitetyt TEN- ja MALLA-minimiparit eivät jakaudu joko-tai-tyyppisesti eri merkitysten kesken eivätkä näin esitetyt toisinnot välttämättä vastaa eri merkitysten jakautumista TEN- ja MALLA-rakenteiden kesken aidon murreaineiston valossa. Esimerkiksi keinon merkitystä ilmaistaan korpusaineistossa lähinnä MALLA-rakenteella ja vastaavasti varsinaista tapaa kuvataan sekä TEN- että MALLA-rakenteella (Hamunen 2017: 131-132, 139). Näiden varauksien jälkeenkin on kuitenkin vakuuttavaa, että MATTA-rakenteen yksi keskeinen funktio on toimia kielteisenä tavanilmauksena infinitiivijärjestelmän sisällä. Näin se muodostaa tavan merkityskirjon ympärille ryhmittyvien TEN- ja MALLA- 
rakenteiden kanssa lähikonstruktioiden ryhmän, joita ei yhdistä infinitiivien ilmeinen rakenteellinen samankaltaisuus vaan semantiikka. Tässä lähikonstruktioiden pesyeessä MATTA-rakenne toimii kontraarisena vastinparina TEN- ja MALLA-rakenteille.

\section{MATTA-rakenteen kehyssemanttinen tulkinta}

Edellä luvussa 3 olen korostanut MATTA-rakenteen semanttista yhteyttä kahteen muuhun infinitiivirakenteeseen (TEN ja MALLA) osana väljästi tavan merkityksen yhdistämää lähikonstruktioiden ryhmää. Tässä luvussa negaation rinnalle nousevat finiittirakenteen ja MATTA-rakenteen kuvaamien tapahtumien temporaaliset suhteet.

\subsection{Kehyssemantiikasta}

Kehyssemantiikka (esim. Fillmore 1982; Fillmore \& Atkins 1992; Lindén ym. 2017) tarjoaa hyödyllisen teoreettisen taustan niiden MATTA-rakenteiden tulkintaan, joilla ei ole ilmeistä kytköstä myönteisiin lähirakenteisiin (vrt. lukuun 3). Kehyksillä tarkoitetaan "mitä tahansa käsitteiden järjestelmää, jossa tunnettaessa yksikin käsite on tunnettava koko järjestelmä, johon kyseinen käsite kuuluu; toisin sanoen kun yksi tällaisen järjestelmän käsite esitellään tekstissä tai keskustelussa, kaikki muutkin käsitteet ovat automaattisesti tarjolla" (Fillmore mas. 111, suom. MH; ks. myös Petruck 1996: 1). Erityisesti lekseemit eli sisältösanat herättävät (evoke) puhujan tai kuulijan mielessä joukon muita käsitteitä, joille on usein olemassa oma nimityksensä sanastossa. Esimerkiksi suomen lekseemi ( $\mathrm{LU}=$ lexical unit) saunoa aktivoi kehyksen SAUNOA, jonka yhteyteen kuuluvat muun muassa sellaiset kehyselementit $(\mathrm{FE}=$ frame element) kuin SAUNA, SAUNOJA(T), KIUAS, (LÖYLY) VESI, (LÖYlY)KAUHA, LÖYlY, LAUdE, HEITTÄÄ (VETTä), ViHTA/VASTA, VIHTOA/VASTOA, HIкоILLA. Tyypillisesti verbit aktivoivat kehyksen, jonka kehyselementteinä ovat verbien syntaktiset dependentit. Silti yhtä lailla myös olioita nimeävät substantiivit aktivoivat oman kehyksensä. Esimerkiksi löyly aktivoi kehyksen LÖYLY, jonka kehyselementtien kokoelma (esim. KIUAS, (LÖYLY)KAUHA, (LÖYLY)VESI, HÖYRY) on usein vain mimimaalisempi kuin tapahtumia ja laajempia episodeja nimeävillä verbeillä. (Ks. Ruppenhofer, Ellsworth, Petruck, Johnson, Baker \& Scheffczyk 2016: 7-8.)

Kielellisen ilmaisun kannalta syntaktiset rakenteet edustavat konventionaalisia ja rajallisia tapoja ilmaista kehysten välisiä suhteita, mutta epistemologisesti kehykset muodostavat periaatteessa rajattoman verkoston. Kehys SAUNOA tuo mieleen ensi sijassa juuri edellä mainittuja löylytilaan liittyviä toimintoja ja asioita, mutta myös peseytymis- (KYLPË̈, PESEYTYÄ, SHAMPOO, SUIHKU yms.) ja pukeutumistilaan (RII-

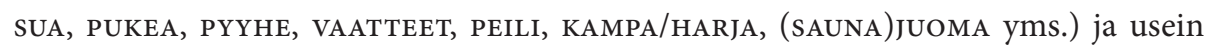
saunan yhteyteen liittyviä muita kehyksiä (AVANTO, UIDA, JäRVI, POLTTOPUU yms.). Näin ajatellen kehyssemantiikan kehykset keskinäisine suhteineen ovat malli ihmisen tiedon- ja käsitteidenjäsennyksen yleisperiaatteesta, jossa tietoverkko on pohjimmiltaan rajoittamaton mutta rakentumisperiaatteiltaan kokemuksellisesti motivoitu.

Koska pyrin artikkelissani avaamaan nimenomaan MATTA-rakenteiden semantiikkaa niiden välittömissä lauseyhteyksissä, on mielekästä tarkastella kehyksiä niiden leksee- 
mien suhteen, joihin MATTA-rakenteella on syntaktinen suhde. Näin kehyssemanttinen tieto edustaa konstruktioiden merkityksen kuvausta. Tästä seuraa analyysia edesauttavia rajoituksia: Ensiksi eksplikoitujen kehysten ja kehyselementtien määrä rajoittuu niihin lekseemeihin, jotka syntaktisessa rakenteessa esiintyvät. Toiseksi kehyssemanttinen tieto voidaan linkittää kielelliseen ilmaukseen sanojen kieliopillista funktiota (subjekti, objekti ym.) ja semanttista roolia (AGENTTI, PATIENTTI ym.) koskevan tiedon kanssa. Tämä edustaa konstruktiokieliopin analyysitapaa ja vastaa määritelmällisesti konstruktion käsitettä muodon ja merkityksen yhteenliittymänä. Kolmanneksi perinteisen lauseajattelun predikaattilähtöistä ja lauseenjäsenien valenssisuhteisiin perustuvaa syntaktis-semanttista analyysia seuraten predikaatin (tai konstruktion muun keskeisen sanan) aktivoimaan kehykseen liittyviä kehyselementtejä voidaan jakaa keskeisiin (core FE) ja ei-keskeisiin (noncore $\mathrm{FE}$ ). Edelliset ovat tyypillisesti argumentteja ja jälkimmäiset adjunkteja.

\section{Taulukko 3.}

Ei-leksikaalinen AKTIVITEETTI-kehys (ks. FrameNet, Frame Index, s.v. Activity, https://framenet.icsi.berkeley.edu/fndrupal/framelndex, suom. MH).

Aktiviteetti ${ }^{18}$

\begin{tabular}{ll}
\hline Kehyselementit (FEs) & \\
\hline Ydin: & Agentti ottaa osaa aktiviteettiin. \\
\hline agentti [Agent] & $\begin{array}{l}\text { Tämä kehyselementti (FE) kuvaa aktiviteettia, } \\
\text { johon agentti ottaa osaa. }\end{array}$ \\
\hline aktiviteetti [Act] (ei ilmaistu) & $\begin{array}{l}\text { Tämä kehyselementti (FE) kuvaa sitä aikamäärää, } \\
\text { jonka aktiviteetti kuluttaa. }\end{array}$ \\
\hline Ei-ydin: & $\begin{array}{l}\text { Mikä tahansa aktiviteettia koskeva kuvaus, jota ei- } \\
\text { vät kata jotkin spesifimmät kehyselementit (FEs), } \\
\text { esimerkiksi toissijaiset seuraukset (esim. hiljaa, ää- } \\
\text { nekkäästi) tai yleiset tapahtumaan verrattavat ku- } \\
\text { vaukset (esim. samalla tavoin). Se voi liittyä myös } \\
\text { agentin havaittaviin ominaisuuksiin, jotka vaikut- } \\
\text { tavat toimintaan (esim. röyhkeästi, viileästi, harki- } \\
\text { tusti, innokkaasti, varovasti). }\end{array}$ \\
\hline tapa [Manr] & $\begin{array}{l}\text { Tämä kehyselementti (FE) kuvaa paikkaa, jossa } \\
\text { aktiviteetti tapahtuu. }\end{array}$ \\
\hline paikka [Place] & $\begin{array}{l}\text { Tämä kehyselementti (FE) kuvaa aikaa, jolloin } \\
\text { aktiviteetti tapahtuu. }\end{array}$ \\
\hline aika [Time] &
\end{tabular}

18. Määritelmä: Tämä on abstrakti kehys kestollisille aktiviteeteille, joissa agentti siirtyy aktiviteetin tilaan, pysyy siinä määrätyn ajan ja poistuu tästä tilasta joko saavuttamalla aktiviteettiin kuuluvan päämäärän tai vain lopettamalla sen. Agentin toiminta aktiviteetissa on intentionaalista. Tämä kehys on pääasiassa tarkoitettu tyypillisimpien [spesifeille verbilekseemeille] periytyvien kehyselementtien (FE) luettelointiin ja aktiviteetin vaiheiden (aloitus, meneillään olo ja lopetus, jotka muodostavat kukin alakehyksen) esittelyyn. Tätä kehystä tulisi verrata [vielä abstraktimpaan] prosessi-kehykseen. (Ks. FrameNet, Frame Index, s.v. Activity, https://framenet.icsi.berkeley.edu/fndrupal/framelndex; suomennos ja hakasulkeissa olevat tarkennukset $\mathrm{MH}$.) 
Taulukko 3 havainnollistaa englannin AKTIVITEETTi-kehystä (Activity) ja sen kehyselementtejä. Kyseessä on melko abstrakti, ei-leksikaalinen kehys, mikä tarkoittaa sitä, että useat verbit aktivoivat sen. Tähän perustuu myös sen arvo havainnollistuksena; se ei rajaudu yksittäisiin verbilekseemeihin, ja sitä voi soveltaa myös suomeen. Näin se toimii edustavana yleistyksenä toimintatyypistä myös valtaosalle MATTA-aineiston kuvaamista tilanteista.

Esimerkki 19 edustaa sellaista englannin kielen lausetta, joka sekä havainnollistaa AKTIVITEETTI-kehystä että ilmentää taulukossa 3 kuvattuja kehyselementtejä. AKTIVITEETTI-kehyksen ja kehyselementin aktiviteetti ([Act]) ero on siinä, että koko kehys edustaa sitä käsitekokonaisuutta, joka koostuu luetelluista kehyselementeistä. Verbilekseemin kuvaama toiminta (jog, eat, read ym.) siis edustaa yhtä AKTIVITEETTIkehyksen kehyselementeistä täsmentäen aktiviteetin luonteen.

(19) $[\text { Every Saturday }]_{[\text {Time }]}[\mathrm{John}]_{[\text {Agent] }}[\text { jogs }]_{[\text {Act }]}[\text { one hour }]_{[\text {Dur }]}[\text { calmly }]_{[\text {Manr }]}[$ in the forest nearby his home $]_{[\text {Place }]}$.

Esimerkin 19 verbin jog ('hölkätä) leksikaalisesti täsmentämän AKTIVITEETTI-kehyksen ainoa pakollinen jäsen on argumentti John eli kehyselementti agentti. Kaikki muut kehyselementit (aika, kesto, tapa ja paikka) toteutuvat syntaktisesti adjunkteina (ks. esim. Fillmore 1994). Seuraavassa alaluvussa tarkastelen MATTA-rakenteen merkityksiä kehyssemanttisesti edellä esitetyn taustoituksen valossa.

\subsection{Kehykset, kehyselementit ja MATTA-rakenteen tulkinnat}

Alaluvussa 3.3 kuvasin MATTA-rakenteen semantiikkaa suhteessa TEN- ja MALLArakenteisiin ja esitin sen olevan kontraarinen vastinpari näille tapaa (väljästi) kuvaaville infiniittisille konstruktioille. Negaatio erottaa MATTA-rakenteen TEN- ja MALLArakenteista. Taulukosta 2 (s. 371) huomataan, että vain osa MATTA-rakenteen merkityksistä on tulkittavissa tällä tavalla. MATTA-rakenteen kuvausta ei siis voi kokonaisuudessaan kytkeä muihin infinitiivirakenteisiin. Erityisesti taulukon 2 ryhmä "muu (rakenne/tulkinta)" jää luvussa 3 esitetyn lähikonstruktiotulkinnan ulkopuolelle. $\mathrm{Ne}$ tapaukset edustavat sellaisia rakenteen käyttöjä, joille ei löydy myönteisiä merkitysparalleeleja TEN- ja MALLA-rakenteista. Lisäksi näiden rakenteiden (abessiivi)kiellon taustalle hahmottuu (verbivartalon) kuvaama prosessi (ks. Langacker 1991: 134), jonka temporaalinen suhde finiittirakenteen prosessiin on [-samanaikainen]. Taulukossa 4 on nähtävissä vielä tällaisten MATTA-rakenteiden esimerkkiesiintymät aineistossa.

Taulukko 4.

MATTA-rakenteiden vartaloverbin kuvaaman toiminnan temporaalinen suhde finiittirakenteen kuvaamaan toimintaan.

\begin{tabular}{c|c|l|c}
$\begin{array}{l}\text { Finiittirakenteen } \\
\text { tilannetta edeltävät }\end{array}$ & $\begin{array}{l}\text { Finiittirakenteen } \\
\text { tilannetta seuraavat }\end{array}$ & $\begin{array}{l}\text { Rinnastuksen- } \\
\text { omaiset }\end{array}$ & Yhteensä \\
\hline 173 & 25 & 26 & 224 \\
\hline
\end{tabular}


Kuten nähdään, valtaosa esimerkeistä (173 es.) kuvaa finiittirakenteen kuvaamaa toimintaa edeltäviä tapahtumia (esim. 20a-c).

(20) a. lähti taas syämätit töihiin (DMA, Loimaa)

b. ei niä enniä missiä talos ies karvomisveistäkiä, ko voiki syyvvyä jo karvomatta (SMS, Kurkijoki, s.v. karvomisveitsi)

c. ja tämä tuli poes kylypemätän ni sem minä näe jotta se pelekäsi nyt semmosta ruumista (LA, Kontiolahti)

Näissä MATTA-rakenne kuvaa jonkin odotuksenmukaisen toiminnan toteutumattomuutta ennen finiittirakenteen kuvaamaa toimintaa ja tämän tilan voimassaoloa: esimerkissä 2oa 'x ei syönyt vaan lähti töihin', esimerkissä $20 b$ 'ei karvota [= poisteta voista karvoja] vaan syödään sellaisenaan' ja esimerkissä 2oc poistutaan saunasta pesemättä. MATTA-rakenteiden verbivartalot kuvaavat siis tapahtumia, joiden tyypillinen, konventionaalinen tai luonnollinen järjestys ennen hallitsevaa rakennetta ei toteudu ja joissa tämä toteutumattomuus on finiittirakenteen ilmaisemaa toimintaa luonnehtiva. König (1995: 83) esittää tällaisille tulkinnan "absence of expected attendant circumstance" ('odotuksenmukaisen myötätapahtumisen puute', suom. MH). Ilmiö liittyy miratiivisuuteen. Sillä tarkoitetaan yleensä kieliopillista kategoriaa, joka ilmaisee puhujan yllättyneisyyttä tai kuvatun tilanteen odotuksenvastaisuutta (ks. DeLancey 1997). ${ }^{19}$

Vastaavasti finiittirakenteen kuvaaman toiminnan jälkeisiä tapahtumia kuvaavat tapaukset ovat aineiston perusteella selvästi vähälukuisempia ( 25 es.). Esimerkeissä $21 \mathrm{a}-\mathrm{b}$ MATTA-rakenteen verbivartalon kuvaaman toiminnan kytkentä finiittirakenteen ilmaisemaan toimintaan on kuitenkin käsitteellisesti kiinteämpi kuin esimerkeissä 20a-c: alkoholin liiallisesta nauttimisesta seuraa fysiologisista lainalaisuuksista johtuen nukahtaminen tai tajuttomuus (esim. 21a) ja maailman "läpäisemisestä" väajäämättä kuolema (esim. 21b). Verbien kuvaamia toimintoja yhdistää kausatiivinen kytkös (Herlin 1998: 99-118).

(21) a. Kyl miäs nys sentääv viis ryyppyä kannattaa ilmal lanttumata ['sammumatta'] (SMS, Metsämaa, s.v. kannattaa)

b. ei kukaak kualematat tätä mailmaa läpäse (DMA, Laihia)

Rinnastuksenomaiset tapaukset ovat aineiston valossa kooltaan vähälukuinen ryhmä. Ajatuksella MATTA-rakenteen verbivartalon ilmaiseman toiminnan temporaalisesta määrittelemättömyydestä suhteessa finiittirakenteen ilmaisemaan tilanteeseen tarkoitan sitä, että verbien välinen ajallinen suhde jää indifferentiksi. Rinnastusta kuvaa Kalliokosken (1989: 83-89) esitys, jossa ilmaistut asiat - tässä finiittirakenteen toiminta ja MATTArakenteen ilmaisema tapahtumattomuus - vain esiintyvät yhdessä tai yhteisessä kehyksessä ja niiden keskinäinen suhde perustuu siihen, mitä ilmaistuista asioista maailmassa

19. Kiitän huomiosta Virittäjän nimetöntä arvioijaa. 
yleisesti tiedetään. Toisin kuin tapaa (väljästi) kuvaavat MATTA-rakenteet, jotka edellyttävät tapahtumien samanaikaisuutta, ja edellä kuvatut ennen- ja jälkeen-tulkintaiset rakenteet, rinnastuksenomaiset MATTA-rakenteet tulevat finiittirakenteiden adjunkteina tulkituiksi lähinnä sen maailmantiedon valossa, että tietyt asiat esiintyvät usein yhdessä tai ylipäätään tapahtuvat osana jotain kokonaisuutta.

Esimerkissä 22 kuvataan hirsirakentamista, jossa sammaltamisen puutteella viitataan siihen, että hirsikehikossa hirsikertojen väliin ei ole asetettu tiivistävää sammalta. Sammaltaminen jää myös temporaalisesti epäspesifiksi finiittirakenteen kuvaaman toiminnan suhteen: ei ole yksiselitteistä, onko sammaltamattomuus ollut rakentamisen aikaista (sammaltiivistys jokaisen hirsikerran päälle ennen seuraavan kerran asennusta) vai kehikon valmistumisen jälkeistä (sammallus valmiin kehikon hirsikertojen välejä tilkiten). Se ei ole olennaista mutta sammaltamatta jättäminen ylipäätään ja tämän tilan voimassaolo on, sillä sammaltaminen on ollut tavanomainen menettelytapa hirsiseinän lämpöeristämisessä.

(22) se [rakennus] on kehälle hakattu ilman sammaltamata (SMS, Hattula, s.v. kehä)

Tähän mennessä kuvaamieni produktiivisten MATTA-rakenteiden semantiikka pelkistyy aineiston valossa karkeasti TEN- ja MALLA-vastineellisiin (ks. taulukkoa 2 s. 371) ja muihin (ks. taulukkoa 4 s. 374). Erityisesti tässä on korostettava, että kaikki nämä MATTA-rakenteet ilmaisevat tapaa (väljästi) luonnehtiessaan finiittirakenteen kuvaamaa toimintaa. Sen sijaan abessiivisen kiellon käsitteellinen taustarakenne ("myönteinen vastine") suhteutuu temporaalisesti eri tavoin finiittirakenteeseen.

Määritelmäni mukaan MATTA-rakenteet ovat finiittirakenteen vapaita adverbiaaleja eli adjunkteja. Finiittirakenne tai peräti finiittiverbi on siinä mielessä hallitseva, että lauseella kuvattava kokonaistilanne rakentuu sen varaan: finiittisyys ankkuroi tilanteen deiktisesti, osallistujien suhteet ovat finiittiverbin kuvaaman kehyksen välittämiä ja määräämiä, ja adjunkti-infinitiivien tulkinta riippuu infinitiivin nimeämän kehyksen suhteesta finiittiverbin kehykseen. Juuri verbien kuvaamien kehysten keskinäisiin suhteisiin tarvitaan kehyssemantiikkaa. Tätä hankaloittaa se, että esimerkiksi konstruktiokieliopin formaalissa kuvauksessa kehyssemanttinen kuvaus on melko kehittymätöntä, mikä vaikeuttaa tulkintaan vaikuttavien semanttisten mekanismien eksplikointia. Joka tapauksessa MATTA-rakenteen morfosyntaksiin sinänsä ei ole kiteytynyt edes viitteenomaista suhdetta tavan merkityksiin. Infinitiivin tunnus - $m A$ nominaalistaa (eifiniittistää) prosessia kuvaavan verbivartalon (ks. Langacker 1987: 247), abessiivi kuvaa puuttumista, ja vasta kokonaisuuden $V+m A t t A$ adjunktisuhde finiittirakenteeseen emergoi ilmausyhteydessään erilaiset tavan tulkinnat ja muut semanttiset relaatiot.

Kuvio 3 kuvaa mahdollisimman yleisellä ja leksikaalisesti spesifioimattomalla tasolla MATTA-rakennetta konstruktiona finiittirakenteen yhteydessä. Finiittirakenteet ovat erilaisia argumenttirakennekonstruktioita, joissa verbin valenssilla on keskeinen vaikutus ilmauksen osallistujien määrään, rooleihin ja erityisesti kehyselementteihin. Samoin finiittisen verbilekseemin nimeämä kehys toimii keskeisenä aihiona tilannekuvauksen kokonaisuuden rakentumisessa. Kuvion 3 ARGUMENTTIRAKENNE-kuvauksessa samaistus- 
muuttujilla (\#1-3) linkitetään konstruktioon liittyvien eri osarakenteiden kehyssemantiikkaa ja valenssia $(\theta=$ semanttiset roolit, $\mathrm{gf}=$ lauseenjäsenfunktiot $)$ koskevaa informaatiota keskenään.

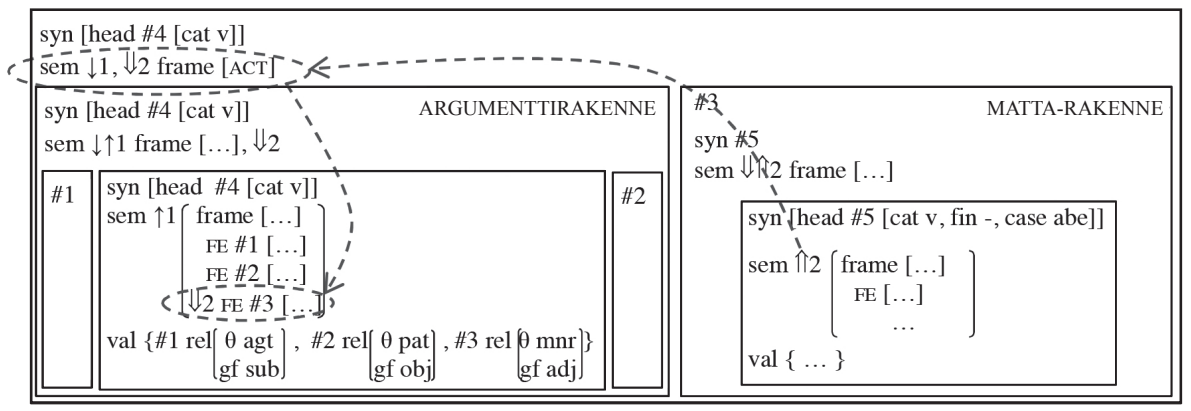

Kuvio 3.

Argumenttirakennekonstruktion ja MATTA-rakenteen semanttiset kytkennät. ${ }^{20}$

MATTA-rakenteen kannalta olennaista on se, että se on yhtäältä ARGUMENTTIRAKENNEkonstruktion valenssipotentiaalin valinnainen jäsen eli adjunkti (\#3 rel [gf adj]) ja näin myös sen kehyselementti ( $\mathrm{FE} \mathrm{\# 3)} \mathrm{ja} \mathrm{toisaalta} \mathrm{verbirakenteena} \mathrm{se} \mathrm{nimeää} \mathrm{oman} \mathrm{kehyk-}$ sensä ja saa omia kehyselementtejään. Jälkimmäistä seikkaa ei ole esitetty kuviossa 3 kovin tarkasti, koska MATTA-rakenne ja finiittirakenne usein jakavat osin samat kehyselementit (esim. argumentteina edustuvat) ja koska tämä seikka ei ole MATTA-rakenteen merkitystulkinnan kannalta tässä keskeisintä.

Keskeisempää sen sijaan on se, että kuvattujen rakenteiden semantiikan lähde osarakenteissa ja merkitysten yhdistyminen komponenttirakenteissa esitetään nuolilla. Yksinkertaiset nuolet $(\downarrow \uparrow)$ kuvaavat argumenttirakenteen osien semantiikan keskinäistä integroitumista, paksummat nuolet $(\Downarrow \Uparrow)$ adjunktikonstruktion (MATTA-rakenne) integroitumista argumenttirakennekonstruktioon. Kuten huomataan, MATTA-rakenne on argumenttirakennekonstruktion adjunkti ja sen semanttinen rooli on tapa $(\theta \mathrm{mnr})$. Se siis kuvaa MATTA-infinitiivin verbivartalon kuvaaman prosessin tai sen lopputuloksen esiintymättömyyttä finiittirakenteen kuvaaman ja temporaalisesti ankkuroidun prosessin yhteydessä ja sitä luonnehtien. Sen sijaan sen tulkinta argumenttirakenteen kehyselementtinä jää kuvauksen tällä tasolla avoimeksi (FE \#3 [...]) (ankkuroinnista ks. Langacker 1991: 96-141). ${ }^{21}$

Huomionarvoista on, että argumenttirakennekonstruktion sisällä argumentteja vastaavien lekseemien (ja NP:iden) roolit kehyselementteinä (FE \#1 ja FE \#2) sekä perinteiset semanttiset roolit $(\theta)$ määräytyvät suoraan verbilekseemin ja konstruktion yhteis-

20. Selitteet: ACT = aktiviteetti(kehys), adj = adjunkti, agt = agentti, case = sija (esim. abe $=$ abessiivi), cat $=$ kategoria $($ esim. verbi $(v)$, substantiivi $(n)), F E=$ kehyselementti, fin $+/-=$ finiittisyys, frame $=$ kehys, $\mathrm{gf}=$ kieliopillinen funktio, head = rakenteen pää, $\mathrm{mnr}=$ tapa, obj = objekti, pat = patientti, rel = relaatio (rooli + funktio), sem = semantiikka, sub = subjekti, syn = syntaksi, val = valenssi.

21. Tulkinnan täsmentymättömyys argumentteja vastaavien kehyselementtien (FE \#1 [...], FE \#2 [...]) osalta johtuu ensi sijassa leksikaalisen semantiikan puuttumisesta kuviosta 3, ts. siitä, että kuvio 3 kuvaa ei-leksikaalisia konstruktioita. Erityisesti kehyselementissä FE \#3 vaikuttaa myös sen ulkopuolisuus suhteessa argumenttirakennekonstruktion inherentteihin kehyselementteihin (vrt. core ja non-core FE). 
pelin perusteella. Sama koskee MATTA-rakenteen argumentteja, ja sikäli sitä voisi pitää argumenttirakennekonstruktiona. Tämä lauseenjäsenfunktioiden, semanttisten roolien ja myös kehyselementtien kytkös on argumenttirakennekonstruktioiden ajatuksen taustalla vaikuttanut keskeisin teoreettinen löydös (esim. Leino 2010: 77-81). Kuitenkin adjunktit, kuten MATTA-rakenne, voivat olla monitulkintaisia ja niiden merkitys usein kehkeytyy käyttöyhteydessään eli finiittirakenteen muodostamassa paikallisessa kontekstissa. Tätä kuvaa kuvion 3 isoin, nimeämätön laatikko, jossa argumenttirakennekonstruktion ja MATTA-rakenteen kehyssemanttiset tiedot yhdistyvät (ks. kuvion 3 katkoviivallinen ympyröinti). Niinpä MATTA-rakenteen tulkintaa ARGUMENTTIRAKENNE-konstruktion adjunktina ja kehyselementtinä tulee tarkastella juuri tätä kokonaisilmausta kuvaavalla tasolla ja erityisesti semanttisen kehystiedon yhdistymisen kehkeyttämänä (ks. nuolet).

Kuviossa 4 esitän tässä artikkelissa esiin tulleet MATTA-rakenteen merkitystulkinnat. Ne ilmenevät kehyselementteinä (vrt. kuviossa 3 FE \#3 [...]) ja perustuvat finiitti- ja infinitiiviverbien kuvaamien kehysten sisältämän semanttisen tiedon keskinäiseen yhdistymiseen (sem $\downarrow_{1}, \Downarrow_{2}$ frame [ACT]). Kuvaan tässä vain kuvion 3 nuolien yhdistämää ja ympyröityä semantiikkaa koskevia seikkoja (ks. kuvion 4 lihavoidut kohdat), sillä muut konstruktioiden ominaisuudet ovat kaikissa мATTA-rakenteissa muuten samat.

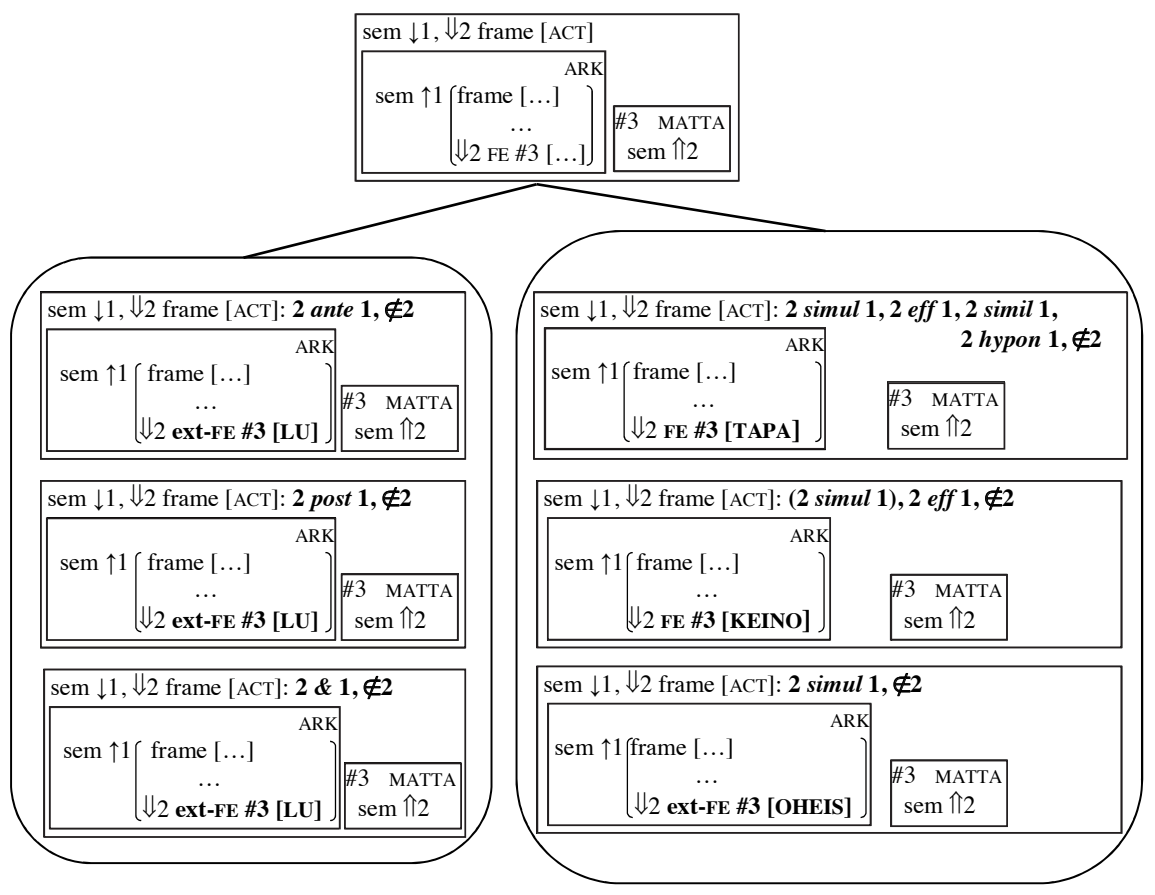

Kuvio 4.

MATTA-rakenteen merkitystulkinnat konstruktiokieliopin kehyssemanttisessa kuvauksessa (ARK = argumenttirakennekonstruktio, MATTA = MATTA-rakenne).

Kuvaus on leksikaalisesti spesifioimaton ja skemaattinen. Se esittää kahden AKTIVITEETIN, finiittiverbin ja MATTA-infinitiiviverbin, kehyssemanttisen tiedon yhdistymistä 
ja tähän liittyvien eri merkitystekijöiden vaikutusta MATTA-adjunktin tulkintaan finiittirakenteen kehyselementtinä. Kuten edellä on käynyt ilmi. kaikkien MATTA-adjunktien semanttiseksi rooliksi voi ajatella tavan, mutta sen tarkempi tulkinta finiittirakenteen kehyselementtinä on riippuvainen verbien keskinäisistä semanttisista suhteista. Kuvion 4 oikeanpuoleiset kolme kuvausta vastaavat luvussa 3 esiteltyjä lähikonstruktiotulkintoja. Niitä kaikkia yhdistää se, että toteutuessaan infinitiivin kuvaama toiminta olisi samanaikainen finiittiverbin toiminnan kanssa (2 simul[taneous] 1). Lisäksi niitä yhdistää abessiivin vaikutuksesta se, että infinitiivin kuvaama toiminta ei toteudu $(\notin 2){ }^{22}$

Mitä enemmän verbikehyksiä yhdistävät erilaiset semanttiset relaatiot, sen läheisempiä verbit ovat merkitykseltään. Tämä on ilmeistä varsinaista tapaa kuvaavissa MATTA-rakenteissa: niissä verbien kuvaamat toiminnat ovat samanaikaisia, infinitiiviverbin kuvaama toiminta vaikuttaa finiittiverbin toimintaan (2 eff[ective to] 1), se kuvaa samaa toimintaa kuin finiittiverbi ( $2 \operatorname{simil[}[\operatorname{ar}$ to] 1) ja infinitiivi on leksikaalissemanttisesti finiittiverbin hyponyymi (2 hypon[ymy for] 1). Sen sijaan keinoa ilmaisevissa MATTA-rakenteissa tulkintaan vaikuttava välttämätön relaatio on vain infinitiivin toiminnan vaikuttavuus finiittiverbin toimintaan (ks. temporaalisuudesta alav. 15); edellisellä edesautetaan jälkimmäisen saavuttamista. Viimein oheisteon tulkinta ei vaadi kuin verbien kuvaamien toimintojen samanaikaisuutta.

Tavasta ja keinosta oheisteko eroaa myös niin, että kehyselementtinä sitä voi pitää ulkoisena (ext[ernal]-FE); se ei kuvaa mitään finiittiverbin kehykselle inherenttiä merkitystä. Tässä suhteessa samankaltaisia ovat kuvion 4 vasemmanpuoleiset MATTArakenteet, jotka ovat myös ulkoisia kehyselementtejä finiittirakenteessa. Niitä yhdistää keskenään se, että infinitiivin vartaloverbi kuvaa finiittirakenteen toimintaa edeltävää ( 2 ante 1 ), seuraavaa ( 2 post 1 ) tai temporaalisesti kokonaan indifferentiksi jäävää ( 2 \& 1) toimintaa. Niille ei myöskään ole esitettävissä selviä kehyssemanttisia tulkintoja, vaan finiittirakenteen ankkuroimassa ajassa leksikaalisen yksikön (eli verbivartalon) kuvaama toiminta esitetään yksinkertaisesti tapahtumattomana.

Kokonaisuutena tarkastellen kuvio 4 korostaa sitä, että adjunktina toimivan MATTArakenteen tulkinnat ilmausyhteydessään riippuvat verbikehysten erilaisista semanttisista relaatioista, jotka vaikuttavat infinitiivin semanttista roolia tarkempaan tulkintaan kehyselementtinä. ${ }^{23}$ Karkeammalla semanttisten roolien tasolla kaikki MATTA-rakenteet kuvaavat (negatiivista) tapaa (val $\{$ rel $[\theta \mathrm{mnr}]\})$. Näin kuvattua merkitsemisen mekanismia voi yleisesti ottaen soveltaa myös muihin adjunkteina toimiviin infinitiivirakenteisiin.

\section{Lopuksi: MATTA-rakenne kompleksina kohtauksena}

Tässä artikkelissa olen kuvannut MATTA-rakenteen erilaisia merkitystulkintoja paikallisessa kontekstissa eli finiittirakenteen adjunktina. Karkealla semanttisten roolien ta-

22. Käytän formalismissa abessiivin kuvaaman puutteen merkityksessä merkkiä $\notin$ 'ei sisälly, ei ole x:n jäsen' (ks. Nikanne 1997).

23. Menettelytavan merkitystä ei ole kuviossa 4 kuvattu, sillä se koskee lähinnä tiettyjä spesifejä leksikaalisia ryhmiä (esim. pyydystysverbit, rakentamisverbit). 
solla rakenne luonnehtii finiittirakenteen ilmaiseman toiminnan tapaa ilmoittaen, mikä jää sen suhteen tapahtumatta. Se nimeää toiminnan, jolla on nollaekstensio suhteessa finiittirakenteen kuvaamaan toimintaan.

Rakenteen tarkemmat tulkinnat perustuvat abessiivin negaatiotyyppisen käsiterakenteen luonteeseen (ks. kuviota 1). ${ }^{24}$ Abessiivi kuvaa kompleksista kohtausta (ks. lukua 2), joka hahmottaa etualaistetun puuttumisen taustalle positiivisen käsitteistyksen, jossa kuvattu entiteetti esiintyy. MATTA-rakenteessa taustalle hahmottuva entiteetti on abstrakteimmillaan kognitiivisen kieliopin termein verbivartalon kuvaama prosessi. Olen kuitenkin luvuissa 3 ja 4 osoittanut, että verbien keskinäisillä ajallisilla suhteilla on yhteys MATTA-rakenteen oman kompleksisen kohtauksen hahmottamiseen, joten kuva on hieman tätä mutkikkaampi.

Kuviossa 5, johon seuraava selostus viittaa, tiivistän artikkelin väitteen (vrt. negaatiota havainnollistavaan kuvioon 1): Finiittiverbit kuvaavat aikaan ankkuroituja prosesseja (musta palkki aikajanalla), joiden tempukseen MATTA-rakenne adjunktina kiinnittyy. On huomattava, että abessiivin johdosta juuri MATTA-verbin kuvaaman toiminnan puuttuminen eli tapahtumattomuus on finiittiseen aikaan sijoittuvaa (korrespondenssiviiva $\notin 1-3$ aikajanalle). Siis kompleksisen kohtauksen aktiivinen rakenne on finiittirakenteen ajallisesti ankkuroimaa. Sen sijaan abessiivin hahmottaman kompleksisen kohtauksen taustaksi muotoutuva positiivinen toiminta voi tulla tulkituksi temporaalisesti ainakin kolmella tavalla. Se voi olla finiittiverbin kuvaaman toiminnan kanssa samanaikaista, sitä edeltävää tai sitä seuraavaa (korrespondenssiviivat 1-3 aikajanalle).

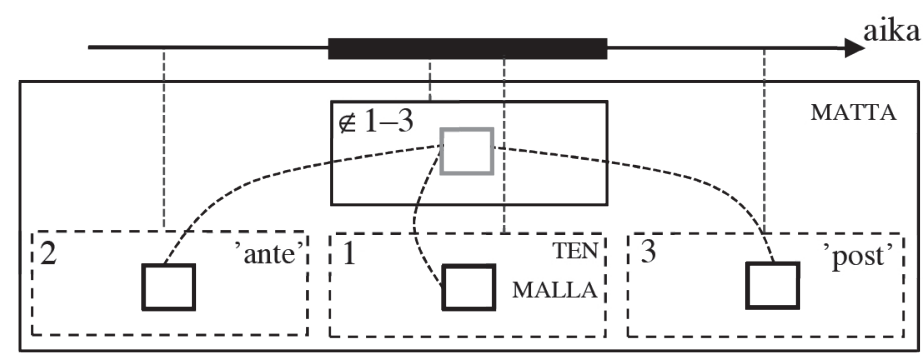

Kuvio 5.

MATTA-rakenteen temporaaliset tulkinnat kompleksina kohtauksena.

Ensimmäinen tutkimuskysymykseni nosti tarkasteltavaksi, voiko MATTA-rakenteen ajatella olevan TEN- ja MALLA-rakenteiden kielteinen vastine. Samalla nämä kolme infinitiivirakennetta muodostaisivat lähikonstruktioiden ryhmän. Luvussa 3 vastasin tähän myönteisesti. Rakenteet jakavat samat tavan (väljästi) merkitykset: varsinaisen tavan, keinon, oheisteon ja menettelytavan. Olennaista on nyt huomata, että TEN- ja MALlArakenteiden voi ajatella edustuvan MATTA-rakenteen kuvaaman kompleksisen kohtauk-

24. Tarkkaan ottaen negaatio (kielto) ja abessiivi (karitiivisuus) eivät ole aivan sama asia, mutta kielteisyys ja puuttuminen ovat käsiterakenteeltaan riittävän samankaltaisia tätä artikkelia ajatellen. 
sen taustarakenteena (korrespondenssiviiva 1 entiteetistä entiteettiin). Niiden voi ajatella edustuvan MATTA-rakenteen käsiterakenteessa positiivisena taustana, mikä vahvistaa lähikonstruktio-tulkintaa.

Toisena tutkimuskysymyksenä esitin, onko MATTA-rakenteella kytkentöjä muihin myönteisiin rakenteisiin. Luvussa 4 kävi ilmi, että MATTA-rakenteella on myös käyttöjä, joissa kompleksisen rakenteen taustakäsitteistys tulkitaan finiittirakenteen kuvaamaa toimintaa edeltäväksi tai seuraavaksi (ks. kuviossa 5 korrespondenssiviivat 2 ja 3 aikajanalle). Lisäksi rinnastuksenomaiset MATTA-rakenteet jäävät temporaalisen tulkinnan suhteen epämääräisiksi: niitä ei voi ilmaista infinitiivirakenteilla. Kuitenkin mikäli ajatellaan kompleksisen kohtauksen osarakenteiden suhdetta lauseenvastikkeen (MATTA-rakenne) ja (myönteisen) lauseen välisenä suhteena (ks. Ikola 1974: 44-47), kiellon taustarakenteen voisi ilmaista tapaa (väljästi) ilmaisevilla siten että tai niin että -rakenteilla: [finiittirakenne] siten niin että $\mathrm{V}_{\text {mennyt }} \sim \mathrm{V}_{\text {menemätön }} \sim \mathrm{V}_{\text {futurinen }}{ }^{25}$ Tämä ilmentää lähinnä sitä, että kiellolla on yleisesti myönteinen taustarakenne osana käsitteistystään ja myös tämä on mahdollista ilmaista kielellisesti.

Konstruktiona MATTA-rakennetta - samoin kuin TEN- ja MALLA-rakenteitakin voi pitää argumenttirakennekonstruktiomaisena (Goldberg 1995), mutta sen teoreettisempi kuvaus on jätettävä toiseen yhteyteen. Infinitiivin $m A$-tunnus ei-finiittistää verbivartalon ja tekee siitä kognitiivisen kieliopin termein atemporaalisen relaation (ks. Langacker 1987: 247). Abessiivi -ttA esittää verbi(vartalo)n kuvaaman toiminnan kompleksisena kohtauksena. Kokonaisuutena MATTA-rakenne on sekä syntaktisesti että semanttisesti alisteisessa suhteessa finiittirakenteeseen. Syntaktisesti tämä näkyy adjunktisuhteena ja semanttisesti niinä kehyssemanttisina tulkintoina, jotka olen esitellyt siitä luvuissa 3 ja 4 vastauksena kolmanteen tutkimuskysymykseen (millaisessa yhtenäisessä kehyksessä MATTA-rakenteen voi kuvata). Sen eri tavan merkitykset ovat infinitiiviverbin ilmaisemaa toimintaa nimenomaan suhteessa finiittiverbin kuvaamaan toimintaan. Näin infinitiivirakenteet tarjoavat kielellisen mahdollisuuden esittää tapahtumia, jotka koostuvat useammasta yksittäisen verbin kuvaamasta toiminnasta sen kielisysteemiin kuuluvan rajoituksen vallitessa, että (rinnastamattomassa) yksinäislauseessa voi olla vain yksi finiittiverbi.

\section{Lähteet}

Aineistolähteet

DMA = Digitaalinen muoto-opin arkisto. Signum 753. Käytettävissä Kielipankissa. https://www. kielipankki.fi/ (12.4.2015).

LA = Lauseopin arkisto. Käytettävissä Kielipankissa. https://www.kielipankki.fi/ (6.5.2015).

SMS = Suomen murteiden sanakirja, osat 1-8 (kirjainväli A-kurvottaa). Helsinki: Kotimaisten kielten tutkimuskeskus.

25. Vastaavasti MATTA-rakenteen parafraasistaminen ilman että-lauseella on mahdollista. 


\section{Kirjallisuuslähteet}

Cannelin, Knut 1930: Kielteisyyden ilmaiseminen suomenkielessä. - Virittäjä 34 s. 238-244. DeLAnCey, Scot T 1997: Mirativity. The grammatical marking of unexpected information. Linguistic Typology 1 s. 33-52. https://doi.org/10.1515/lity.1997.1.1.33.

Fillmore, Charles J. 1982: Frame semantics. - The Linguistic Society of Korea (toim.), Linguistics in the morning calm. Selected papers from SICOL-1981 s. 111-137. Seoul: Hanshin Publishing Company.

- 1985: Frames and the semantics of understanding. - Quaderni di Semantica 6 s. 222-254.

- 1994: Under the circumstances (Place, Time, Manner, etc.). - Berkeley Linguistic Society 20 s. 158-172. http://dx.doi.org/10.3765/bls.v20i1.1478.

Fillmore, Charles J. - Atkins, Beryl T. 1992: Toward a frame-based lexicon. The semantics of RISK and its neighbours. - Adrienne Lehrer \& Eva Feder Kittay (toim.), Frames, fields and contrasts s. 75-102. New Essays in Semantic and Lexical Organization. Hillsdale, NJ: Lawrence Erlbaum Associates.

FrameNet $=$ https://framenet.icsi.berkeley.edu/fndrupal/ (18.12.2017).

Fried, Mirjam - Östman, Jan-Ola 2004: Construction grammar. A thumbnail sketch. - Mirjam Fried \& Jan-Ola Östman (toim.), Construction grammar in a cross-language perspective s. 11-86. Constructional Approaches to Language 2. Amsterdam: John Benjamins Publishing Company. https://doi.org/10.1075/cal.2.o2fri.

Givón, Talmy 1979: On understanding grammar. New York: Academic Press. https://doi. org/10.1016/C2013-0-10728-3.

Goldberg, Adele E. 1995: Constructions. A construction grammar approach to argument structure. Chicago: University of Chicago Press.

Hamunen, Markus 2012: Koloratiivirakenne, liike ja tapa. - Ilona Herlin \& Lari Kotilainen (toim.), Verbit ja konstruktiot s. 104-140. Suomi 210. Helsinki: Suomalaisen Kirjallisuuden Seura.

2017: Juosten vai juoksemalla? Infiniittisten TEN- ja MALLA-rakenteiden semantiikkaa ja murrejakaumaa. - Sananjalka 59 s. 125-153.

Herlin, Ilona 1998: Suomen kun. Suomalaisen Kirjallisuuden Seuran Toimituksia 712. Helsinki: Suomalaisen Kirjallisuuden Seura.

Herlin, Ilona - Leino, Pentti - VisapäÄ, LaUra 2005: Kas siinä pulma. - Ilona Herlin \& Laura Visapää (toim.), Elävä kielioppi. Suomen infiniittisten rakenteiden dynamiikkaa s. 9-38. Suomalaisen Kirjallisuuden Seuran Toimituksia 1021. Helsinki: Suomalaisen Kirjallisuuden Seura.

Hilpert, MARTin 2014: Construction grammar and its application to English. Edinburgh: Edinburgh University Press.

Horn, Laurence R. 2001: A natural history of negation. CSLI Publications. The David Hume Series. Philosophy and Cognitive Science Reissues. Stanford: Leland Stanford Junior University.

Horn, Laurence R. - Wansing, Heinrich 2017: Negation. - Edward N. Zalta (toim.), The Stanford encyclopedia of philosophy. https://plato.stanford.edu/archives/spr2017/entries/negation/ (19.12.2017).

Huumo, Tuomas 2007: Force dynamics, fictive dynamicity, and the Finnish verbs of 'remaining. - Folia Linguistica 41 s. 73-98. https://doi.org/10.1515/flin.41.1-2.73.

Iкоl A, Osmo 1974: Lauseenvastikeoppia. Tietolipas 7. Helsinki: Suomalaisen Kirjallisuuden Seura. 
— 1996: Abessiivin käyttö suomen yleiskielessä ja murteissa. - Sananjalka 38 s. 25-34.

Iкоla, Osmo - Palomäki, Ulla - Koitto, Anna-Kaisa 1989: Suomen murteiden lauseoppia ja tekstikielioppia. Suomalaisen Kirjallisuuden Seuran Toimituksia 511. Helsinki: Suomalaisen Kirjallisuuden Seura.

ISK = Hakulinen, Auli - Vilkuna, Maria - Korhonen, Riitta - Koivisto, Vesa - Heinonen, Tarja Riitta - Alho, Irja 2004: Iso suomen kielioppi. Helsinki: Suomalaisen Kirjallisuuden Seura.

JÄÄSKeläInen, Petri 2004: Instrumentatiivisuus ja nykysuomen verbinjohto. Semanttinen tutkimus. Jyväskylä Studies in Humanities 22. Jyväskylä: Jyväskylän yliopisto.

KAlliokosKi, Jy RKI 1989: Ja. Rinnastus ja rinnastuskonjunktion käyttö. Suomalaisen Kirjallisuuden Seuran Toimituksia 497. Helsinki: Suomalaisen Kirjallisuuden Seura.

Kotilainen, LAR I 2005: Lähikonstruktioiden dynamiikkaa. Mikäs on ollessa, mikäs on olla ja mikäs on ollakseen. - Ilona Herlin \& Laura Visapää (toim.), Elävä kielioppi. Suomen infiniittisten rakenteiden dynamiikkaa s. 39-71. Suomalaisen Kirjallisuuden Seuran Toimituksia 1021. Helsinki: Suomalaisen Kirjallisuuden Seura.

- 2007: Kiellon lumo. Kieltoverbitön kieltokonstruktio ja sen kiteytyminen. Suomi 197. Helsinki: Suomalaisen Kirjallisuuden Seura.

KöNIG, EKKEHARD 1995: The meaning of converb constructions. - Martin Haspelmath \& Ekkehard König (toim.), Converbs in cross-linguistic perspective. Structure and meaning of adverbial verb forms - adverbial participles, gerunds s. 57-95. Empirical Approaches to Language Typology 13. Berlin: Mouton de Gruyter.

LANGaCker, Ronald W. 1987: Foundations of cognitive grammar. Volume I. Theoretical prerequisites. Stanford, Cal.: Stanford University Press.

- 1991: Foundations of cognitive grammar. Volume II. Descriptive Application. Stanford, CA: Stanford University Press.

- 2008: Cognitive grammar. A basic introduction. Oxford: Oxford University Press. https:// doi.org/10.1093/acprof:oso/9780195331967.001.0001.

Lappalainen, Tirna 1993: Nykysuomen II infinitiivin instruktiivin ja III infinitiivin adessiivin syntaksia ja semantiikkaa. Suomen kielen pro gradu -tutkielma. Helsingin yliopisto.

LEINO, JА А ко 2003: Antaa sen muuttua. Suomen kielen permissiivirakenne ja sen kehitys. Suomalaisen Kirjallisuuden Seuran Toimituksia 9oo. Helsinki: Suomalaisen Kirjallisuuden Seura.

2010: Adele E. Goldberg - väitöskirjalla klassikoksi. - Pentti Haddington \& Jari Sivonen (toim.), Kielentutkimuksen modernit klassikot s. 71-97. Helsinki: Gaudeamus.

Lindén, Krister - Haltia, Heidi - Luukkonen, Juha - Laine, Antti O. Roivainen, Henri - VÄisänen, NiIna 2017: FinnFN 1.o. The Finnish frame semantic database. - Nordic Journal of Linguistics 40 s. 287-311. https://doi.org/10.1017/ So332586517000075.

Miestamo, Matt i 2005: Standard negation. The negation of declarative verbal main clauses in a typological perspective. Empirical Approaches to Language Typology 31. Berlin: Mouton de Gruyter.

Miestamo, Matti - Tamm, Anne - Wagner-Nagy, Beáta 2015: Negation in Uralic languages. Introduction. - Matti Miestamo, Anne Tamm \& Beáta Wagner-Nagy (toim.), Negation in Uralic languages s. 1-41. Typological Studies in Language 108. Amsterdam: John Benjamins Publishing Company. https://doi.org/10.1075/tsl.108.o1int.

NikAnNe, URPO 1997: Suomen infiniittisten adjunktien temporaalinen tulkinta. - Virittäjä 101 s. $338-357$. 
NURMI, KLAUS 2017: Yksinhuoltajaäiti sinnitteli rahatta kolme viikkoa - kieltäytyi lähtemästä Kelan konttorista. - Helsingin Uutiset 5.5.2017. https://www.helsinginuutiset.fi/artikkeli/515799yksinhuoltajaaiti-sinnitteli-rahatta-kolme-viikkoa-kieltaytyi-lahtemasta-kelan (20.1.2018).

Pantermöller, Marko 2010a: Marginaalisija kielensuunnittelun fokuksessa - 18oo-luvulla käyty keskustelu abessiivin päätevarianteista. - Sirkka Saarinen, Kirsti Siitonen \& Tanja Vaittinen (toim.), Sanoista kirjakieliin. Juhlakirja Kaisa Häkkiselle 17. marraskuuta 2010 s. 65-80. Suomalais-Ugrilaisen Seuran Toimituksia 259. Helsinki: Suomalais-Ugrilainen Seura.

- 2010b: Der finnische Abessiv. Ein Kasus zwischen spontanen Wandel und gezielter Sprachplanung. Veröffentlichungen der Societas Uralo-Altaica. Band 8o. Wiesbaden: Harrassowitz Verlag.

Petruck, Miriam R. L. 1996: Frame semantics. - Jef Verschueren, Jan-Ola Östman, Jan Blommaert \& Chris Bulcaen (toim.), Handbook of Pragmatics 1996 s. 1-13. Amsterdam: John Benjamins Publishing Company. https://doi.org/10.1075/hop.2.fra1.

Ruppenhofer, Josef - Ellsworth, Michael - Petruck, Miriam R. L. - JohnSon, Christopher R. - Baker, Collin F. - SCheffCzyK, Jan 2016: FrameNet II. Extended theory and practice. https://framenet2.icsi.berkeley.edu/docs/r1.7/book.pdf (13.3.2017).

SAlMINEN, HilJa 2003: Lönnrotin adessiivi ja abessiivi. Infinittisten tavan adverbiaalien historiaa. Suomen kielen pro gradu -tutkielma. Helsingin yliopisto.

Siro, PaAvo 1964: Suomen kielen lauseoppi. Helsinki: Tietosanakirja Oy.

Sirola-Belliard, Maija 2016: Suomen komitatiivi. -ine ja kanssa. Acta Universitatis Tamperensis 2219. Tampere: Tampere University Press.

Toivainen, Jorma 1985: Partitiivin syntaksi. Turun yliopiston suomalaisen ja yleisen kielitieteen laitoksen julkaisuja 25. Turku.

Vihervalli, Auroora 2016: Abessiivinominien käyttöfunktiot nykykielessä. Suomen kielen pro gradu -tutkielma. Helsingin yliopisto.

Vilkuna, MaRia 1992: Referenssi ja määräisyys suomenkielisten tekstien tulkinnassa. Suomi 163. Helsinki: Suomalaisen Kirjallisuuden Seura.

- 2015: Negation in Finnish. - Matti Miestamo, Anne Tamm \& Beáta Wagner-Nagy (toim.), Negation in Uralic languages s. 457-485. Typological Studies in Language 108. Amsterdam: John Benjamins Publishing Company. https://doi.org/10.1075/tsl.108.17vil.

VISAPÄ̈̈, LAURA 2008: Infinitiivi ja sen infiniittisyys. Tutkimus suomen kielen itsenäisistä Ainfinitiivikonstruktioista. Suomalaisen Kirjallisuuden Seuran Toimituksia 1181. Helsinki: Suomalaisen Kirjallisuuden Seura. 


\section{The cognitive semantics of the MATTA-construction}

This article deals with the meanings of the $m A$-infinitive abessive (e.g. syö-mättä 'without eating', juo-matta 'without drinking', nukku-matta 'without sleeping') as an adjunct in phrasal expressions in the light of dialect corpora (MATTA-construction). The data has been gathered from Lauseopin arkisto (LA, Syntax Archive), Digitaalinen Muotoopin arkisto (DMA, Digital Morphology Archive), and from volumes 1-8 of Suomen murteiden sanakirja (SMS, Dictionary of Finnish dialects). The research concentrates on issues such as 1) what type of negation the adverbial MATTA-construction constitutes on a general level and 2) what adverbial meanings can be inferred from it. To examine these questions, the author has employed the (traditional) syntactic-semantic analysis of the corpus data and Frame Semantics as a branch of Construction Grammar.

As an adverbial, the MATTA-structure is conceptually attached to a frame defined by the dominant finite structure, and its meanings depend on the relationship between the finite and the infinite structures. Factors influencing this interpretation are lexical semantics (e.g. hyponymy), subject interpretations (the same or different subjects), temporality (the same or different temporal affinities), and other frame semantic relationships between states of affairs. It becomes apparent that the Te-infinitive instructive (TEN-structure, e.g. syö-den 'by eating'), the $m A$-infinitive adessive (MALLAstructure, e.g. syö-mällä 'by (means of) eating'), and the MATTA-structure constitute a semantic subgroup, i.e. infinitives of manner and means within the Finnish infinitive system. These are associated with divergent meanings of manner. However, the MATTA-structure also carries other meanings of negation due to the complex conceptual structure of the abessive. 


\section{MATTA-rakenteen kognitiivista semantiikkaa}

Tässä artikkelissa käsitellään $m A$-infinitiivin abessiivin adjunktikäyttöjen eli MATTArakenteen (esim. syömättä, juomatta, nukkumatta) merkityksiä lauseen kokoisissa ilmauksissa murreaineistossa. Aineistona käytetään Lauseopin arkiston (LA) ja Digitaalisen muoto-opin arkiston (DMA) kokoelmia sekä Suomen murteiden sanakirjan (SMS) osien 1-8 sana-artikkeleita. Tutkimus pureutuu muun muassa siihen, 1) millainen kiellon tyyppi adjunktina toimiva infinitiivirakenne yleisesti on ja 2) millaisia adverbiaalisia merkityksiä sille on tulkittavissa. Kysymysten selvittelyyn käytetään korpusaineiston (perinteistä) syntaktis-semanttista analyysia ja kehyssemantiikkaa konstruktiokieliopin sovellusalana.

Adverbiaalina MATTA-rakenne kiinnittyy hallitsevan rakenteen ilmaisemaan kehykseen ja sen merkitystulkinnat riippuvat infinitiivirakenteen ja finiittiverbin keskinäisistä suhteista. Tulkintaan vaikuttavia tekijöitä ovat leksikaalinen semantiikka (esim. hyponymia), subjektitulkinnat (sama- tai erisubjektisuus), temporaaliset suhteet (sama- tai eriaikaiset asiaintilat) sekä muut tapahtumien väliset kehyssemanttiset suhteet. Käy ilmi, että Te-infinitiivin instruktiivi (TEN-rakenne, esim. syöden), $m A$ infinitiivin adessiivi (MALLA-rakenne, esim. syömällä) sekä MATTA-rakenne muodostavat suomen infinitiivijärjestelmässä oman semanttisen ryhmänsä, joka ilmaisee erilaisia myötätapahtumisen merkityksiä, kuten tapaa, keinoa ja oheistekoa, finiittiverbillä kuvatun tapahtuman lisäksi. Ne ovat siis niin kutsuttuja lähikonstruktioita, jotka kuvaavat samoja tavan (väljästi) merkityksiä. Lisäksi MATTA-rakenteen abessiivin käsiterakenteen kompleksisuudesta seuraa se, että rakenteen suhde finiittirakenteeseen voi olla myös väljempi kuin TEN- ja MALLA-rakenteilla.

Kirjoittajan yhteystiedot (address):

etunimi.sukunimi@helsinki.fi

ORCID: 0000-0003-2786-6392

Kirjoittaja on suomen kielen väitöskirjatutkija Helsingin yliopistossa. 